\title{
1960’’ı Yıllarda Türk Solunun Almaşıklığı: Sosyalizm ve Milliyetçilik
}

\author{
Berkan GÜNGÖR*
}

Geliş Tarihi (Received): 12.04.2021 - Kabul Tarihi (Accepted): 13.09.2021

\section{$\ddot{\mathbf{O z}}$}

Türkiye'de milliyetçilik genelde sağ ideolojilere mahsus bir kavram olarak düşünülmekte sol ideoloji ise, milliyet veya din olgusundan arınmış ve hatta ona karşı olacak söylemlerle bağdaştırılmaktadır. Milliyetçi merkez sol olarak ön plana çıkan ulusalcılık fikri bu algıyı biraz yıksa da, aslında sol ve milliyetçilik arasındaki ilişkide incelemelerin Türk Solu'nun zirve yaptı̆̆ 1 1960'lı yıllar göz ardı edilerek yapılmış olduğu görünmektedir. 1960'l1 yıllarda görece Türkiye tarihindeki en hegemonik günlerini yaşayan Türk Solu, çeşitli formlarda kendini göstermiştir. Bu hareketlerin birçoğunun Kemalizm'in ve antiemperyalist bir ruhtan kaynaklı milliyetçiliğin etkisinden çıkamadıkları rahatlıkla söylenebilecektir. Radikal birkaç örnek dışında sol hareketlerde bariz bir milliyetçilik vurgusu vardır. Özellikle Yön, TïP ve MDD hareketlerinin bazı söylemlerinde hâkim bir Türk milliyetçiliği (ulusalc1lığı) gözlemlenmektedir. Keza benzer şekilde TKP/ML hareketi de bariz bir şekilde Kürt milliyetçisidir. Sol hareketlerin milliyetçiliğe yaklaşımları çoğunlukla sömürge karşıtı ve tepkisel milliyetçilik olarak gelişmiştir. 1960'lı yıllardaki sol hareketlerin Milliyetçiliğe yaklaşımları ise kimi zaman pragmatist nitelikler taşısa da, samimi inançlar barındırdığı da inkâr edilemeyecektir. Çalışmada tespit edilen önemli bir nokta ise Sosyalist tezlerle öne çıkan sol hareketlerin, milliyetçi argümanları sosyalizmin temel argümanlarından bile daha çok vurgulamış olmalarıdır. Hülasa 1960'lı yıllarda Türk solu milliyetçi ve sosyalist bir almaşıklığa sahip görünmektedir.

Anahtar Kelimeler: Milliyetçilik, Türk Solu, Sosyalizm, Kemalizm, 1960’lar

\section{The Alternativeness of the Turkish Left in the 1960s: Socialism and Nationalism}

\begin{abstract}
Nationalism is generally considered a right ideology, while left ideology is associated with anticommunist discourses such as non-nationalism or irreligious in Turkey. Although the idea of left-wing nationalism (ulusalc1lik), which has come to the fore as the nationalist center-left, slightly demolishes this perception, the 1960s, when the Turkish Left reached its peak, are ignored. The Turkish Left, relatively which lived its freest days in the history of Turkey with the 1961 Constitution, has manifested itself in various forms. It can be easily said that many of these movements could not get out of the influence of Kemalism and nationalism originating from an anti-imperialist spirit. Apart from a few radical examples, there is an obvious emphasis on nationalism in left movements. Especially in some discourses of Yön, TIP and MDD movements, a dominant Turkish nationalism is observed. Likewise, the TKP / ML movement is clearly Kurdish nationalist. Left movements' approach to nationalism has mostly developed as anti-colonial and reactive nationalism. Although their approach to nationalism sometimes carries pragmatist qualities, it cannot be denied that it contains sincere beliefs. An important point determined in the study is that the left movements that came to the fore with Socialist theses emphasized the nationalist arguments even more than the basic arguments of socialism. In short, the Turkish left seems to have a nationalist and socialist alternative in the 1960s.
\end{abstract}

Keywords: Nationalism, Turkish Left, Socialism, Kemalism, 1960s

\footnotetext{
* Öğretim Görevlisi, Kastamonu Üniversitesi, Rektörlük, bgungor@kastamonu.edu.tr Doktora Öğrencisi, Ankara Hacı Bayram Veli Üniversitesi, Siyaset ve Sosyal Bilimler
} 


\section{Giriş}

Milliyetçilik ve sosyalizm farklı iki ideolojik perspektif ortaya koydukları için birbirleriyle ilgisiz hatta birbirine rakip ideolojiler olarak görülmektedir. Çünkü sosyalizm için bir yapay olgu olarak görülen milliyetçilik, ezilen sınıfların sömürü gerçeğini görmelerini engelleyen bir perde mesabesindedir. Aynı konumlanma milliyetçilik için sosyalizm söz konusu olduğunda görülür, sosyalizm, milliyet duygusunu ve milli kimliği-kültürü vb. yok sayıp beynelmilel bir bakış açısı ve tutum ortaya koyduğu için milliyetçiliğin ana argümanlarını yok sayarak kendini onun karşısında konumlandırır. Düşünce tarihi bu iki temel ideolojinin karşıt konumlanmasının zaman zaman ortak düşman algısı karşısında bazı grupların-kişilerin şahsında birleşebildiğini de göstermektedir. Bu ortak düşmanlar elbette ki, emperyalizm ve kapitalizmdir. Sömürgeci bir dış düşmana ve onun içerdeki komprador izdüşümlerine karşı verilecek bir mücadele aynı hassasiyete sahip ideoloji ve taraftarlarını birleştirebilecektir. $\mathrm{Bu}$ hassasiyet örneğin Türkiye'de sol ve milliyetçiliğin (daha uygun bir ifade ile ulusalcılığın) ortak bir dış düşman tehdidi algısı (Amerikan emperyalizmi) ve onun içerdeki uzantılarına karşı verilecek bir mücadeleyi Cumhuriyetin kurucu değerlerinden alan bir ulusalc1lıkla harmanlayarak sol sosyalizme tahvil ederek yeni bir mücadele alanı oluşturacaktır.

Bolşevik İhtilali sonrası Doğu'da Osmanlı entelektüellerinden bir grup tarafından kurulmuş olan ilk komünist partilerden birisi olan Türkiye Komünist Partisi'nin, kurucu kadrosu bile ulusal düzeyde hâkim bir ulus milliyetçiliğinin; uluslararası düzeyde de İkinci Enternasyonal'in yani sosyalizmin daha reformist versiyonlarının etkisi altında kalmışlardır (Cilasun, 2008, s. 62). Tunçay'a (2001, s. 197) göre de Mustafa Kemal ile Mustafa Suphi'nin aralarındaki ortak paydalar modernleşme ve milliyetçiliktir. Yani Türk Solu'ndaki milliyetçilik söylemlerinin aslında 1960’lı yıllardan çok daha evvel başladığı söylenebilecektir.

Tartışmasız son iki yüzyılda en uygun ve belki de tek siyasal yönetim birimi olarak kabul edilen şey ulustur. Ulusların da dokunulmaz haklarından en temeli kendi kaderlerini tayin hakları yani siyasal bağımsızlıktır. Tam da bu noktada milliyetçilik ideolojisi devreye girmektedir. Nitekim milliyetçilik ideolojisi, diğer ideolojileri geride bırakan bir popülariteye sahip olmuştur (Heywood, 2012, s. 149). Yine de 19. Yüzy1ldan itibaren dünya gündemini derinden etkileyen milliyetçilik için her yerde benzer süreçlerden geçtiği söylenemeyecektir (Bostanc1, 1999, s. 43).

Milliyetçilik genelde bir vatanseverlik algısına atıfta bulunmaktadır. Sadece siyasal hedefler sunmaz; aynı zamanda insanlara "kim olduklarını" söyler (Turan, 2017, s. 185). Milliyetçilik, kolektif bir kimlik (milli kimlik) etrafında toplanan siyasi topluluklara aidiyet 
biçimi ve duygusal bağl1lığı; nihai aşamada da bir ulus devlete sadakati ifade etmektedir (Erdem, 2020, s. 29).

1960'l1 yılların sonlarında Türkiye'de yaşanan ekonomik ve toplumsal dönüşümler ülkedeki dinamikleri büyük ölçüde değiştirmiştir. Ahmad'a (2012, s. 161) göre ekonomisi neredeyse tamamen tarıma dayalı olan toplumda özel sektör giderek güçlenmiş, bu da toplumda iki yeni siyasal grubun oluşmasına neden olacak ekonomi-politik aktörleri oluşturmuştur: Bunlardan birincisi, giderek bilinçlenen bir işçi sınıfı, ikincisi de kendi çıkarlarını daha da çok savunmaya kararlı sanayi burjuvazisidir. Sanayileşmenin toplumda yaratmış olduğu bir diğer köklü değişim ise ülkenin artık bir tüketim toplumuna dönüşmesidir.

1960’l1 yılların ortalarından itibaren tüm dünyada yükselme gösteren sol hareketlerde, anti-emperyalizm, Amerikan karşı devrimciliği ve kapitalist tüketim toplumuna tepki motivasyonları ulusal sınırları aşmıştır. Yine de sol akımlar ortaya çıktığı her ülkede yerel bir hüviyet kazanmışlardır (Akın, 2008, s. 87). Türk solu da Cumhuriyet'in resmi ideolojisinin etkisi altında kalmış ve hatta giderek milliyetçiliğe eğilimli bir görünüm sergilemiş ya da sergilemek durumunda kalmıştır (Sayın, 2008, s. 578).

Türkiye'nin 1960'lı yıllarında “İkinci Kuvayı Milliye” sloganlarıyla ortaya çıkan sol hareketler, aslında Türkiye'de hiçbir zaman bir “Aydınlanma Devrimi” yaşanmasa da, Cumhuriyet'in kuruluşuna bir Aydınlanma Devrimi rolü yüklemişlerdir. Türk Solu resmi tarihle ve resmi ideolojiyle hesaplaşmadan, bir burjuva ideolojisi olan Kemalizm'den bağımsızlaşmadan kendi gerçekliğine kendi gözleriyle bakamamıştır (Başkaya, 2008, s. 73). Bu yılların Türkiye'sinde üniversite eğitimi görebilmek gibi “büyük bir ayrıcalı̆̆a” sınırlı sayıda genç sahiptir ve bu da onların toplumdaki konumlarını ayrıcalıklı bir hale getirmiştir. Üzerine bir de Atatürk'ün, gençleri Cumhuriyet'i “muhafaza ve müdafaa etmekle” görevlendirmesi eklenince toplumda üniversiteli gençlerin ülke için en iyisini, en doğrusunu ve en güzelini isteyen bir sınıf haline dönüşmesine yol açmıştır (Atılgan, 2017, s. 320).

Zenginliğin ve iktidarın, bir azınlık grubun elinde toplanmış olmasına tepki olarak çıkan sosyalizm, en temel anlamıyla kendisini, toplumsal adaleti savunan, toplumdaki maddi eşitsizlikleri en aza indirmek ve özgürlükleri koruyarak genişletmek isteyen devrimci bir ideoloji olarak tanımlar. Bu ideolojinin özünde üretim, değişim ve dağıtım araçlarının mülkiyetlerinin devletin ya da toplumun elinde bulunduğu, kapitalist düzene karşıt bir sistem yatmaktadır. Sosyalist ideolojinin en önemli kavramı ise toplumsal sınıftır (Turan, 2017, s. 169).

20. yüzyıla gelindiğinde sosyalist hareketler ikiye ayrılmıştır. Bunlardan birincisi Bolşevikleri takip eden devrimci sosyalistler, yani komünistler; ikincisi ise anayasal bir 
politikayı takip eden reformist sosyalistler, ya da sonradan sosyal demokratlar. Komünistler ile sosyal demokratlar arasındaki fark sadece araçsal bir fark olarak görünse de zamanla amaç konusunda da farklı düşünceler belirmiştir. Sosyal demokratlar, sosyalizmin temelinde olan birçok ilkeye sırtlarını dönmüşler ve hatta kimi yazarlar tarafından liberalizmle farksız olarak yorumlanmışlardır (Heywood, 2012, s. 81).

Sosyal demokrasinin güçlenmesinde Sovyetler Birliği’nin totaliter yüzünün ortaya çıkmasının etkisi vardır. Ayrıca 1968 gençlik hareketleri de Marksizm'in Sovyet modeli dışında da ele alınmasını sağlamıştır (Turan, 2017, s. 172). Fransa'nın sosyalist başbakanı Micher Rocard sosyal demokrasiyi Marksizm'e kuramsal ve devrime siyasal bir ihanet, sınıfların işbirliği ve enternasyonalizmden kopma olarak yorumlamıştır. Bunu ise bir eleştiri olarak değil bir beğeni olarak anlatmıştır çünkü kendisi de bir sosyal demokrattır (Kışlalı, 2018, s. 123). Kışlalı'ya (2018, s. 140) göre Kemalizm açıkça bir sosyal demokrasiyi hedeflemektedir.

Türk solunun en büyük zaafi kendisini enternasyonalizmle hiçbir zaman özümleyememesidir. Hâlbuki enternasyonalist olmayan bir harekete sol demek mümkün değildir. Fakat Türk solu milliyetçilik etkisinden bir türlü çıkmayı başaramamış ve bu nedenle de enternasyonalist olamamıştır. Türk solunun bir diğer zaafı da kendisini her zaman toplumun kurtarıcısı olarak görmesidir. Bu da kurtarılmayı bekleyen bir alt tabaka ile kurtarıcı olan bir aydın tabaka ayrımını doğurmuştur. Hâlbuki kurtarıcılık, yani ikamecilik bir burjuva ideolojisidir (Başkaya, 2008, s. 75). Ancak Uğur Mumcu'ya göre ise enternasyonalizm Marksizm'in klasiklerinde kalmıştır (akt. Özbay, 2019, s. 202). O günlerdeki enternasyonalizm ise çok uluslu ve tekelci kapitalizmdir. Bu nedenle de devletçi, himayeci ve sosyalist akımlar, kapitalist enternasyonal güce karşı yerli ve ulusal olmak zorundadırlar.

Marksizm teorisi de Türkiye'de başlangıçta ve ilk yıllarında gerçek manada bir teorisyen bulamamış bu nedenle de Marksizm'in Türkiye'deki teorik birikimi oldukça yetersiz kalmıştır. Bu teorik eksiklikten etkilenen en önemli grup da kuşkusuz ki 1960'larda gelişen sol hareketlerdir. Teorik eksikliğin yanı sıra egemen sınıf ideolojilerinin de etkisini kıramayan Türk Solu, "Kemalizm ve Sosyalizm arasındaki ayrılık çok derin değildir” gibi koşullandırmalara itilmiştir. Hal böyle olunca da bu sol hareketler ideolojik bir şekilsizliğe maruz kalmışlardır (Belge, 2008, s. 109). Marksist yöntem ile Türkiye toplumunun özgüllüğünün ve özgünlüğünün çözümlenmesi gerekirken, sol hareketler sinıf ve üretim ilişkilerini ikinci plana atmış ve hızla milliyetçilik düşüncelerinin içerisine girmişlerdir (Oktay, 1998, s. 53).

Genelde sosyalizm açısından yanlış bir bilinç olarak nitelendirilen milliyetçiliğin sosyalizme karşı bir zafer kazandığından bahsedilmektedir. Bunun nedeni de milliyetçiliğin, 
sosyalizme kıyasla çok daha geniş ve farklı kitlelere hitap edebilme niteliğindendir. Nitekim milliyetçilik bir toplumda farklı cinsiyetlere, farklı gelir düzeylerine ve farklı toplumsal sınıflara aynı anda hitap edebilmeyi başarmıştır (Erdem, 2020, s. 30). Ancak Gellner'a (2018, s. 124) göre ise yaklaşık 8000 farklı dilin konuşulduğu bir dünyada ortalama 200 devletin var olması milliyetçiliğin bariz başarısızlığıdır.

Sosyalizm ve milliyetçilik birbirine zıt kavramlar olarak algılansa da toplumun menfaatini bireylerin menfaatlerinin üzerinde tutması bakımından milliyetçilik, sosyalizm, komünizm, korporatizm, nasyonal sosyalizm ve faşizm göreceli bir ayniyet taşımaktadırlar. Milliyetçilik ve sosyalizmin ayrıldıkları temel nokta toplumu algılama biçimleridir. Milliyetçilik, toplumu "homojenlik" ve "millet" üzerinden tanımlarken belirli sınırlar içerisinde kalmayı tercih eder; sosyalizm ise homojenlik beklentisi olmadan "sömürülen bütün kitleler" ve "toplum" üzerinden tanımlar. Sosyalizmde bireyin konumunu mensup olduğu "sınıf" belirlerken, milliyetçilikte "etnisite" belirler (Cihangir, 2020, s. 200).

Bu çalışmanın amacı da 1960’lı yılların görece özgürlük ortamında kendini ifade etme şansı bulan sol/sosyalist akımların fikirlerinin milliyetçilik söylemleri bakımından değerlendirilmesidir. Her ne kadar să̆ milliyetçilerin antikomünizm propagandalarında solcular milliyetsiz, dinsiz ve bölücü olarak nitelendirilse de (Türkeş, 2019, s. 99), dönemin sol akımlarında da güçlü milliyetçilik söylemleri olduğu dikkate çarpmaktadır. Hatta birçok sol harekette milliyetçi fikirler nedeniyle yol ayrımlarının yaşandığından çalışmanın ilerleyen bölümlerinde bahsedilmiştir.

\section{Yön Hareketinde Milliyetçi Söylemler}

Yön Dergisi 20 Aralık 1961 tarihinde sol muhalefetin sözcülüğünü yapma misyonuyla Ankara'da yayın hayatına başlamıştır. 1960-1971 yılları yani iki darbe arasında Yön dergisi, Milli Demokratik Devrim ve Türkiye İşçi Partisi ile birlikte Türk solunun üç ana akımından birisi olmuştur. Aynı zamanda sol içinde bir okul görevi de gören bu dergi sosyal demokratları, sol Kemalistleri, komünist partilileri bir araya getirmiştir. Türkiye'de sosyalizme ilginin artmaya başladığı dönemlerde çıkarılan ilk sosyalist dergidir (Kaya ve Yücer, 2018, s. 574). 27 Mayıs ihtilalinin getirdiği görece “özgürlükçü” ortam Türkiye'de solun açıkça konuşulmasına ve de örgütlenmesine zemin hazırlamış ve bu zeminden faydalanan Doğan Avcıŏlu, İlhan Selçuk, Mümtaz Soysal, İlhami Soysal, Cemal Reşit Eyüboğlu gibi aydınların öncülüklerinde Yön'ün tohumları atılmıştır. Farklı köktenci ve solcu görüşlerin de dillendirildiği, Marksist fikirlere ardıllarına (Devrim ve Aydınlık) göre daha fazla yer veren ve geniş çaplı bir tartışma kürsüsü haline gelen Yön (Zürcher, 2020, s. 292), aslında bir gazete olarak yayın hayatına başlamış ve akabinde bir dergi formu ile yayın sürecine devam etmiştir. Ancak bilhassa gençler, 
ordu ve aydınlar içindeki radikal sol kesim üzerinde oldukça fazla etkileyici olmuştur ve hatta başyazar Doğan Avcıoğlu bir teorisyen olarak kabul görmüştür. Nitekim Şevket Süreyya Aydemir (1962a, s. 7) Yön'ü bir fikir ve doktrin dergisi olarak tanımlamıştır. Yön'ün temel fikirsel çıkış noktası Kemalizm ile Sosyalizm’i ortak bir potada birleştirebilmektir. Bu bağlamda Marksizm'in sınıfsal çatışma, proletarya diktatörlüğü ve hâkimiyeti gibi kavramlardan ziyade Kemalizm'e ve onun milliyetçi argümanlarına dayanarak bunlar ile sosyalizmi sentezleme çabası gütmüştür (Turhan, 2018, s. 45). Doğan Avcioğlu'na göre sosyalizm Atatürkçülüğün devamı niteliğindedir ve Milliyetçilik, Halkçılık, Devletçilik, İnkılapçılık, Laiklik ve Cumhuriyetçilik ilkelerine dayanmaktadır. Hatta sosyalizm Atatürk devrimlerini geliştirecek ve ileri götürecektir (Avcıoğlu, 1962a, s. 3).

Aydemir (1962b, s. 20), sosyalizm ve Atatürkçülük arasında ilişki kurmanın doğru olduğunu söyler. Ona göre Atatürk ruhunun 1şık tuttuğu milli kurtuluş hareketi emperyalizmi reddeder, ağalığa karşıdır. Devlet işletme ve organlarının özel şahıslar tarafından istismar edilmesine izin vermez; devletçidir. Dini siyasete karıştırmaz. Ayrıca imtiyazsız ve sınıfsız bir millet olma fikri Atatürk'ün buluşudur ve Atatürk emekten yanadır.

Yöncüler, her ne kadar Kemalizm ile entegre olmaya çalışmışlarsa da, Kemalizm'in ya da Cumhuriyet Halk Fırkası'nın (CHF) burjuvaziyi destekleyen politikalarını eleştirmişlerdir. Avcıŏglu (1962c, s. 2) 1923 yılında yaşanan şeyin bir burjuva ihtilali olduğunu, köylüyü milletin efendisi yapacak yolların en baştan tıkandığını, hükümet ile halk arasında kopukluk yaratan bir sınıfın ortaya çıktığını ve halkçı iddialarla kurulan CHF'nin daha ilk günlerinde köy ve kasabalardaki ağaların ellerine geçtiğini söylemiştir. Altan (1961, s. 9), bir memlekette zenginlerin çoğalarak iş yerleri açmalarını ve gariplerin de buralarda çalışma alanı bulmalarını; gariplerin çalıştığını ve baştaki açıkgözün ise gariplere sadece yevmiye verdiğini iğneleyici bir şekilde anlatarak ekonomik liberalizmi ve Türkiye'deki sosyal sistemi eleştirmiştir.

Yön'ün milliyetçilik vurgusunun güçlenmesi 1964-1965'li y1llardan itibaren başlamıştır. İlhan Selçuk’a göre "maskeli milliyetçiler”, "memleketi sömüren yabanı sermaye uşakları" idiler. Gerçek milliyetçilik antiemperyalist bir tavırla kapitalizme karşı durmayı gerektirir. Doğan Avcıoğlu'na göre de sosyalizm sınıf zıddiyetini kaldırarak milli birliği sağlamlaştırır. Milli toplumun temeli emekçi halktır ve gerçek milliyetçilik için de halkçılık ilkesi izlenmelidir. Bu bağlamda Kemalizm'in halkçılık görüşü ve Kuvayı Milliye Ruhu sosyalizm sayılabilecektir (Bora, 2018, s. 610-611). Nitekim Avcığlu “sosyalizm” kelimesi yerine "milli devrimcilik" kavramını kullanmayı tercih etmiş; "milliyetçi-devrimci”" ya da "sol milliyetçi” ifadelerini de kullanmıştır. 
Doğan Avcıŏglu'nun 1968'de yayınlanan Türkiye'nin Düzeni adlı eserinde kullandığ1 “Dünyada en kudretli ve ileri devlet olduğumuz geçmiş yüzyıllar” ifadesi, Bora' ya milliyetçilik anlayışının sadece “antiemperyalist bir yurtseverlik” olmadığını düşündürmüştür (Bora, 2018, s. 611). Avcioğlu'nun liderliğinde hareket eden Yön'de antiemperyalizm söyleminin içeriği milliyetçi fikirlerle desteklenmiş ve bu da merkezine milliyetçiliği oturtan sol bir siyaset görünümü sağlamıştır (Ayçiçek, 2020, s. 1042). Nitekim Avcıoğlu'na göre en ideal çözüm yolu “milliyetçi mücadelenin ancak sosyalist güçlerin öncülügünde” yürütülmesidir. Çünkü “...sömürge kapitalizminin ve emperyalizmin iki büyük dayanağını tasfiye eden milliyetçi hareket, içeride kapitalist gelişme temellerini son derece daraltarak, köklü sosyal ve ekonomik reformlara yönelmiş halkçı ve devletçi bir gidişe açıldĭ̆ için aynı zamanda sosyal bir mücadeledir." (Avcioğlu, 1966a, s. 3).

Yön'e göre Türk Sosyalizmi ülkeyi tehdit eden “Kara ve kızll tehlikelere” karşı, yani faşizm vb. ideolojiler ile "komünizm belasının” önlenebilmesinin yegâne yoludur. Nitekim bu esaslar aslında Kemalizm'in de ifade ettiği hususlardır ki zaten Kemalizm'in altı oku Türk Sosyalizmi'nin temel taşlarıdır. Temelin üzerine çalışma gücü, ferdi istek ve temayüller, yurdun ekonomik kaynakları, bütün imkân ve kabiliyetler ile kültürel durumumuz, gelenek ve göreneklerimiz de eklenerek Türkiye'nin bünyesine uygun yapıcı, ıslahatçı ve demokratik Türk Sosyalizmi yaratılması elzemdir (Karan, 1962, s. 6). Yön'de antikomünist söylemlere sıcça yer verilmesine rağmen anti-Sovyet söylemler yer almamıştır (Yurtsever, 2008, s. 47). Bunun sebebi, Sovyetlerin desteğini kaybetmemek için izlenen pragmatist bir tutum olarak yorumlanabilecektir.

Türkiye'deki köklü problemlere çözüm yollarını devletçilik anlayışı içinde tartışma görevinin Yön’e düştüğünü belirten Ataöv’e (1962, s. 14) göre “her rejim kendi toprağında ve kendi şartlarında en uygun şekilde yeşerir. Türk Sosyalizmi de bu tartışmaların sonunda ortaya çıkacaktır. Ataöv'ün bu yazısından yaklaşık bir yıl sonra Aydemir (1963, s. 8), Yön'ün 56. Sayısında temellerini Türk Milli Kurtuluş Hareketi'ne dayandırdığı Türk Sosyalizminin İlkeleri’ni aşağıdaki şekilde belirlemiştir:

i. Antiemperyalizm: Istiklalcilik

ii. Antikapitalizm: Milli ve halkçı ekonomi

iii. $\quad$ Karma ekonomiyi reddetmeyen fakat parazit bir istismarcılığı reddeden ileri bir devletçilik

iv. $\quad$ Halk için halkla beraber halkçılık. Faydanın halk için kullanılışı yani sosyal adalet. 
v. Mustafa Kemal’in anladı̆̆ manada bir vatan anlamı. Saldırganlı̆̆a ve istilacılı̆̆a karşı çıkış.

vi. Mustafa Kemal'in anladı̆̆ manada bir millet anlamı. Dil, Tarih ve Kültür işlerinde bilimsel bir milliyetçilik.

vii. Devlette, rejimde, dış politikada ve ekonomide milli olmak vasfi.

viii. Demokratik düzende sosyal devlet anlamının işlenmesi ve organlarının yaratılmast.

ix. $\quad$ Milli hayatın bütün kollarını içine alan bir plancılık.

x. Emeğin ve hizmetin korunması ve teşkilatlandırılması. Güçlü ve bağımsız sendikacılık.

xi. Din ve devlet işlerinin kesin olarak ayrılması, laiklik.

Yukarıda da görüleceği üzere, bariz bir şekilde Yön'ün “Türk Sosyalizmi” Kemalizm’in etkisi altında şekillenmiştir. Kemalizm'in 6 ilkesinin izleri yukarıdaki ilkelerde açıkça görülmektedir. Ayrıca yine bu maddelerde Atatürk'e sıkça atıf yapılmıştır.

Karan (1962, s. 6), o günlerde milliyetçiliğin "şoven ve ırkçı Faşist bozuntularının bir istismar aracı" olmaktan kurtulamadığını söylemektedir. "Kara tehlike” olarak adlandırdığı bu kesimleri "Mukaddesatçı şövenler, Hitler kırması Faşist bozuntuları, ırkçılar, Turancılar, örümcek kafalılar, milliyetçi maskesi takmış Atatürk düşmanları, yobazlar, kapkaççılar, karmanyolacılar, Çıfıt pazarı gibi karmakarışık sürüler ve çıkarları baltalanmış vurguncular”, gibi sert sözlerle eleştirmiştir. Gericilikle suçladığı bu kesimlerin içeriden ve dışarıdan da destek gördügünü iddia etmiştir. Hatta Karan'a göre menfaatleri bir olduğu için gericiler ve komünistler işbirliği yapmaktadırlar. Avcıoğlu da iktisadi anlamda ölüm kalım savaşı veren bir ülkede yapılması gereken tek şeyin çözüm yolu bulmak olduğu zamanda, bir takım insanların milliyetçilik etiketine sığınarak fikirsizliklerini gizlediklerini iddia etmiştir. "Fikir fukarası gevezeler" olarak nitelendirdiği bu grubun yanında bir de milliyetçiliği ticari bir menfaat haline getiren bir gruptan bahsetmiştir. Bu grupların yaptıkları tek şeyin ise "Karşılarına dikilen gerçek milliyetçileri komünistlik damgaları yapıştırarak susturmak” olduğunu söylemiştir. Ayrıca Avcıŏglu (1962b, s. 3) gerçek manada milliyetçilerin cevap aradığı şu sorulara, bu grubun asla cevap veremeyeceğini, verecekleri tek karşılığın ise küfür ve iftira olacağını iddia etmiştir:
i. Artan nüfusu nasıl besleyeceğiz?
ii. Açlık tehlikesini nasıl önleyeceğiz?
iii. Bu nüfusa nasıl iş sağlayacă̆ız?
iv. Çocuklarımızı nasıl okutacağız? 


\section{v. Büyük şehirlerin gecekondu diyarı haline gelmesine nasıl son vereceğiz? \\ vi. Köylünün sömürülmesini nasıl durduracă̆ı?? \\ vii. Milleti fakirlikten nasıl kurtaracă̆ız? \\ viii. Milli tasarrufu nasıl artıracă̆ız? \\ ix. $\quad$ Yatırımları nasıl en verimli şekilde kullanacă̆ız?}

Görüldüğü üzere Avcıoğlu milliyetçiliğini "millet için çalışmak" gibi bir eksene oturtmaya çalışmıştır. Sağ milliyetçilerde eksik olarak gördüğü birtakım özellikleri vurgulayarak gerçek milliyetçiliğin kendi hareketleri olduğunu ispatlamak istemiştir. Bu da aslında Avcıoğlu ve Yön hareketinin milliyetçi desteğini kendi saflarına çekebilme çabaları olarak değerlendirilebilecektir.

Avcıŏ̆lu'na (1965, s. 9) göre asıl mesele sosyalizm değil kalkınma; maziye dönük değil; ileriye yönelik Atatürkçü bir program ile devrimcilerin toparlanmasıdır. Atatürk’ün bulduğu devrimci, devletçi, halkçı ve milliyetçi kalkınma yolu sosyalizmin inşasına giden yoldur. Bütün milliyetçilerin meselesi de Atatürkçü bir politika ile ekonomik bağımsızlığı sağlamak olmalıdır. Ekonomik bağımsızlığın mantıki sonucunu ise Sosyalizm teşkil edecektir.

Yön'ü “27 Mayıs’ın çocuğu” olarak niteleyen Yurtsever (2008, s. 59), tüm amacının da daha sol bir anlayışla millici, kalkınmacı ve sosyalist bir program uygulamak üzerine yeni bir 27 Mayıs gerçekleştirmek olduğunu söylemektedir. Ayrıca Yurtsever'e göre Yön, Kemalizm'in 1960’lı yıllardaki uzantısı ve yorumu niteliğindedir. Yön, devrimin zayıf kalışını ve bağımsızlığın kaybedilişini Kemalist ilkelerden ayrılmak olarak yorumlamış; iktidarın ve devrimin sorunlarını kalkınma temelinde ele almıştır. Bunu yaparken yürüttüğü etkili propaganda sayesinde de hem TİP'i hem de MDD'yi aynı sorunu benimsemek zorunda bırakmıştır. Yani sosyalizmin kalkınmaya indirgenmesi bütün Türk solunu etkilemiştir. Uğur Mumcu'ya göre ise az gelişmiş ülkelerde milliyetçilik ve devrimcilik akımlarının birbirleriyle özdeşleştirilerek yükseltilmeleri zorunluydu ve Avcıoğlu da bunun farkındaydı (akt. Özbay, 2019, s. 120). Her ne kadar aynı sorun etrafında uzlaşarak yola çıkmış olsalar da Yön, TìP ve MDD’nin amaç ve yöntemler bakımından birbirlerinden farklı yollar çizdikleri unutulmamalidir.

\section{Türkiye İşçi Partisi’nde (TİP) Milliyetçi Söylemler}

13 Şubat 1961 tarihinde bir grup sendikacı tarafından kurulan Türkiye İşçi Partisi (TIP), ilk yılında bir sendika cemiyeti niteliğinde kalmıştır. Siyasi parti gibi faaliyet gösterebilmek için sosyalist aydınların desteğini arayan TİP, bu arayışında başarılı olmuş ve genel başkanlığına bir akademisyen olan Mehmet Ali Aybar'1 getirmiştir (Bora, 2018, s. 615). Bu partinin kuruluşundan itibaren Kuvayı Milliye ruhuna atıflarda bulunması dönemdeki 
antiemperyalist grupların (Yöncüler hariç) takdirini toplamış; bu tavırdan en çok etkilenenlerden birisi de Mehmet Ali Aybar olmuştur (Aksakal, 2009, s. 91).

Dönemdeki sol konjonktürde antiemperyalizm ve bağımsızlık vurgusu, bunlara ek olarak da Kemalizm ve ulusalcılıkla ilişkilenmek revaçtadır. Türkiye'de boy gösteren sol düşünceler, topluma kendisini kabul ettirebilmek için Kemalizm’e yanaşma kaygıları duymuşlardır. Bu nedenle de sosyalizmden ziyade devletçi-milliyetçi, kalkınmacı ve militarist bir düzlemde ilerlemişlerdir (Aksakal, 2009, s. 83). Aybar, Yön hareketinden de bir davet almış ancak bu davete karşı mesafeli bir tutum izlemiştir. Aybar, Yön'ün militarist motiflerine karş1 demokratik mücadele söylemini geliştirmiş ve bu nedenle de zaman zaman sol arasında kavgalar yaşanmıştır (Aksakal, 2009, s.91).

Yine de TİP bu akımların etkisinde kalmış ve bağımsız dış politikaya da Atatürk Devri'ni örnek göstermiştir. Ülkedeki Amerika Birleşik Devletleri (ABD) üslerinin bulunduğu topraklara "Amerikan işgali altında" olarak bakmışlardır. Tï, Kemalizm'e fazla bağlı kalmamış ancak Kemalizm'i bazen kendi meşruiyetini sağlamak; bazen de mevcut dönemi (1960’lı yıllar) eleştirmek için kullanmıştır. TíP, Solun millici söylemlerini sınıfsal bir söylem ile törpülemiştir (Bora, 2018, s. 617). Onlara göre ulusun çoğunluğu emekçi sinıfından oluştuğuna göre emekçi sınıfın menfaati aynı zamanda Türk Ulusu'nun da yüksek menfaatidir (TİP, 1969a, s. 3).

1964 yılında Aybar, İzmir'de düzenlediği bir kongrede faaliyetlerinin ekseninin tam bağımsızlık olduğunu ifade etmiş ve Atatürkçülüğünü ortaya koymuştur (Aksakal, 2009, s. 92). Ancak yine de Aybar "ceberrut devlet" ya da "Osmanll tipi devlet" gibi ifadeleri ile de Cumhuriyet Halk Partisi'nde (CHP) ve Kemalist devlet geleneğine eleştiriler getirmiştir (Aybar, 2015, s. 139). Bora'ya (2018, s. 621-625) göre Mehmet Ali Aybar 1960’l1 y1llarda, teorik-pratik tutarlılığını Kemalizm'e ve Kemalizm'in milliyetçiliğine yaklaşarak zedelemiştir.Örneğin TİP'in önemli isimlerinden olan ve Kemalizm'in bir burjuva ideolojisi olduğunu düşünen Behice Boran ve Aybar'ın yolları ileride ayrılacaktır.

Aksakal'a (2009, s. 95) göre Aybar, 1968 yılında Çekoslavakya'nın Sovyetler Birliği tarafindan işgal edilmesine tepki gösteren tek sol düşünce adamı olarak dikkat çekmiştir. Genelde Behice Boran ve Mehmet Ali Aybar'ın aralarının bozulması, Aybar'ın bu işgale gösterdiği tepkinin Boran tarafından kabul edilmemesine bağlanmıştır (Zürcher, 2020, s. 293). Fakat Koç (2010, s. 222) ve Yurtsever (2008, s. 75), Boran'ın da o günlerde Milliyet Gazetesi'nde yazdığı bir yazı ile bu işgali oldukça sert bir şekilde eleştirdiğini belirtmiş; bu konuda aslında Aybar ve Boran’ın aynı fikirde olduklarını iddia etmişlerdir. 
Aybar, Yöncüler ve Milli Demokratik Devrim (MDD) anlayışı ile kimi zaman muhtelif sorunlar yaşamıştır. Yön ve MDD’nin militarist tavrına karşı Aybar "güler yüzlü sosyalizm” ilkesini benimsemiştir. Yurtsever'e göre (2009, s. 64) "güler yüzlü” ya da "Türkiye'ye özgü" sosyalizm edebiyatının sadece Aybar'a mal edilmesi yanlıştır nitekim Behice Boran ve Sadun Aren de aynı yaklaşımları paylaşmaktadır. Ancak Koç’un (2010, s. 222) aktarmasına göre ise Aybar'ın sıkça “güler yüzlü sosyalizm” ya da “Türkiye’ye özgü sosyalizm” kavramlarını kullanmasını Sadun Aren, Aybar'ın başkaları ile kendisi arasına bir fark koymak için sosyalizm teorisini değiştirmeyi düşünmeye başlamasına yormuştur. Aren'e göre sosyalizm bir dünya hareketidir, Türkiye’ye özgü diye bir şey yoktur. Ayrıca diğer sosyalistler de "asık yüzlü bir sosyalizm” düşünmemektedir.

Aslında Aybar'ın 5 Nisan 1947 tarihinde Zincirli Hürriyet gazetesinde, Truman Doktrini'ne karşı yazdığı yazı, onun milliyetçilik perspektifi hakkında pek çok ipucu vermektedir. Milletin, ABD yardımlarının bedelini önünde sonunda kanla ödeyeceğini söyleyen Aybar'a göre ABD bir kurtarıcı gibi gösterilmeye çalışılmaktadır. Bu gibi hallerde ise hakikati gören namuslu her Türk'ün mukaddes vazifesi ise hakikatleri haykırmaktır. Yine aynı yazısında Aybar (1947, s. 4), Sovyetlere karşı istiklalimizin korunması için köle olmayı hiçbir Türk'ün kabul etmeyeceğini yazmıştır. Nitekim TİP, 1963 tarihinde yayınlanan bir broşürde gerçek milliyetçiliğin Türk ulusunun içte ve dışta sömürülmesini önlemek olduğunu vurgulamıştır (Bank, 2018, s. 40). Aybar'a (2015, s. 153) göre Türkiye’de sosyalizm için mücadele etmek Amerikan emperyalizmine karşı milli bir kurtuluş mücadelesidir.

TİP'in yaptığı toplumsal tahlilin elli yıl önce batıda yazılmış kitapların bir çevirisinden öte bir şey olmadığını iddia eden Doğan Avcıoğlu'na göre, sadece “iş̧̧i sınıfı öncülü̈̆̈̈̈” ekseninde yapılan politikalar kısır ve hatalıdır. Nitekim TIP'in parlamentodaki temsiliyetinin yeteri kadar güçlü olmaması da bu anlayışın etkisindendir. Çünkü TİP antiemperyalist bir mücadeleyi temel ilkesi kabul etmekte ancak bir burjuva-proletarya ayrımı yaparak da güçleri yıpratmakta, zayıflatmakta ve dağıtmaktadır. Ancak milliyetçi mücadele çevrelerin bilinçlendirilmesi ve kazanılması ile bir açıklığa kavuşacaktır. Türkiye'de emperyalizme ve onun işbirlikçilerine karşı milletçe mücadele etmek elzemdir ve bu nedenle de her türlü sınıf ayrımının etkisinden kurtulmak hayati bir gerekliliktir (Avcıoğlu, 1966b, s. 3).

Aybar'ın Türkiye'ye özgü bir sosyalizmden bahsetmesi ve bu fikriyatını da Kurtuluş Savaşı'nın romantizmiyle bütünleştirmesi, sosyalist teorilerden ziyade Türk milliyetçiliği esasına dayanan fikirler üretmesi sonucu Türk solu tarafından burjuvalıkla, popülizmle ve "să̆a sapmakla" eleştirilmesine neden olmuştur. Nitekim parti içerisinde Behice Boran'ın öncülük ettiği bir grup da Aybar'ın yüksek dozajlı milliyetçilik söylemini benimsememişlerdir 
(Aksakal, 2009, s. 93). Ancak Türkiye Komünist Partisi - Marksist/Leninist (TKP-ML) lideri İbrahim Kaypakkaya (2015, s. 507), Behice Boran’1 da oportünist ve sinsi bir Türk milliyetçisi olarak tanımlamıştır. TİP’li yazar Orhan Silier'e göre TİP'in milliyetçiliği antikomünist Türk solunun dünya solundan farklı olduğunu ve "biz bize benzeriz" fikrini ispatlayarak orijinal olma çabasıdır (akt. Yurtsever, 2008, s. 64). Nitekim TIP (1969a, s. 5), tüzüğünde Türkiye’nin ulusal varlığını ve bağımsızlığını her şeyin üstünde tuttuğunu ifade etmiştir.

Koç'un (2010, s. 192) aktardığına göre 1965 yılındaki seçimlere TİP’in girmesini engellemek, partiyi yıpratmak ve oylarını azaltmak için müthiş bir çaba gösterilmiştir. O kadar ki toplantıların basılması, il-ilçe merkezlerinin aranması, taşlı-sopalı saldırılar ve kışkırtmalar artık sıradan hale gelmiştir. TİP aleyhine yapılan propagandalar genelde sosyalizmin din, ahlak, millet ve vatan gibi değerlere düşman olduğuna dairdir ve her zamanki gibi işe yaramıştır.

1968 olayları başladıktan sonra, Marksizm'in farklı şekillerde yorumlanması sonucu zaten tam anlamıyla birlik olamamış Türkiye sosyalist hareketleri iyice bölünmeye başlamıştır. Bu yıla kadar Yön hareketi hariç diğer sosyalist akımları çatısı altında toplamış olan TİP, toplum üzerindeki etkisini giderek yitirmiştir. $68^{\prime}$ in en ateşli grubu olan öğrencilerin de TİP çatısından ayrılarak MDD'nin etkisine girmeleri ile de olaylar TíP'in kontrolünden çıkmıştır (Koç, 2010, s. 219).

TİP 1960'lı yıllarda Türkiye Komünist Partisi (TKP) kadrosu için de yasal bir yuva hizmeti vermiştir (Zürcher, 2020, s. 284). TKP üyelerinden Gün Benderli Togay ve Bilal Şen'in katıldığı bir muhalefet, TKP merkez komitesini Türkiye'nin gerçeklerinden kopuk olmakla ve ataletle suçlamışlardır. Ayrıca muhalefet grubu millici bir saik ile Kıbrıs politikasını da eleştirmiş ve oradaki Türk azınlığa sahip çıkılması gerektiğini söylemiştir. TKP’nin milli meselelere karşı duyarsız kalışı Bora’ya (2018, s. 640) göre millicilik eksikliğinden değil Sovyetler Birliği Komünist Partisi’ne bağlılığından kaynaklanmaktadır.

TİP 1. Büyük Kongresinde kabul edilmiş olan parti programında altıncı temel ilke olarak belirlenen milliyetçilik hakkında şunlar yazılmıştır (TİP, 1964, s.79):

“Türk milliyetçiliği, yüzyıllardır bir yarı sömürge olarak yaşamış halkımızın yabancı boyunduruğuna, sömürgeciliğine ve sömürücülüğe karşı tepkisinin ideolojik planda ifadesidir.

Kişiliğini Kurtuluş Savaşı'nda bulmuş olan Türk Milliyetçiliği, halktan ayr düşünülemez. Türk Devleti'ne yurttaşlık bă̆g ile bă̆lı olan herkes Türk'tür. Türk Milliyetçiliği, ulusun bütün fertlerini kaderde, kıvançta ve tasada ortak, bölünmez bir bütün sayar; milletimizi, dünya milletleri ailesinin eşit haklara sahip, kişiliği olan bir üyesi olarak, bilimde, teknikte, kültürde, ekonomide ve toplum hayatının her alanında daima yüceltmeyi amaç bilir. Türk milliyetçiliği, başka milletleri aşă̆ı gören, ırkçı, saldırgan ve sömürücü bir ideoloji asla 
değildir. Batıda sömürgeci ve saldırgan çevreler, milliyetçiliği dış sömürücülüğün elinde saldırgan ve başka milletleri küçük gören bir ideoloji haline getirmişlerdir. Türk milliyetçiliği, milletlerin özgürlük ve kardeşçe dayanışma içinde yaşamaları esasını benimsediği için insancıldır. Türk milliyetçiliği, ırkçılık ve ona bağlanan bütün gerici, tutucu görüş ve sonuçları kesinlikle reddeder. Türkiye Cumhuriyeti'ne yurttaşlık bağı ile bağll herkesi Türk sayar ve yurttaşlar arasında din, dil, ırk, mezhep ayrımı ve eşitsizlik gözetmez."

TİP, 1965 yılında yayınladığı seçim bildirisinde Milliyetçilikten, yukarıdaki programında bahsettiği şekilde bahsetmiş ve metnin sonuna bir paragraf eklemiştir (TïP, 1965, s. 18):

“Türkiye İş̧̧i Partisi, başka milletleri aşă̆ gören emperyalizmin yayılma politikasına bayraklık eden, saldırgan, faşist milliyetçilik anlayışını kökten reddeder. Kökü Milli Kurtuluş Savaşımızda bulunan milliyetçiliğimiz, antiemperyalist ve halkçıdır. ',

Yukarıda görüleceği üzere TİP, milliyetçilik vurgularını Kurtuluş Savaşı'na dayandırarak bir nevi kendi milliyetçiliğine toplumsal bir destek sağlama gayesi gütmüştür. Bunun yanı sıra kendi milliyetçilik anlayışlarını haklı çıkarmaya çalışarak, diğer milliyetçi hareketlerin anlayışlarını eleştirmişlerdir. 1969 yılında yayınlan Türkiye İşçi Partisi El Kitabı isimli yayında "TIPP'e göre milliyetçilik nedir?” sorusunun cevabı şu şekilde verilmiştir (TİP, 1969b, s. 70):

"Milliyetçilik milletini sevmek, milletin çoğunluğunu meydana getiren emekçi halkın çıkarlarını her şeyden üstün saymak demektir. Milliyetçilik, Türk milletinin bă̆ımsız yaşamasını istemek demektir. Milliyetçilik her türlü yabancı sömürüye karşı olmak demektir. Milliyetçilik milletimizin bütün kültür ve değerlerine sahip çıkması demektir. Gerçek milliyetçilik, Türkiye Cumhuriyeti'ne yurttaşlık bağı ile bağlı olan herkesi Türk sayar ve yurttaşlar arasında din, dil, ırk, mezhep ayrımı ve eşitsizlik gözetmez. Atatürk'ün milliyetçiliği, batı emperyalizmine karşı bir savaş bayrağıdır. Bugün memleketimizde yabancı sermaye ile işbirliği yapan, memleketimizde kazandıkları paraları İsviçre bankalarında saklayan, batılı kapitalist ülkelerin zenginleri gibi yaşamaya özenenler, memleketimizi yabancılara peşkeş çekenler ve bilerek ya da bilmeyerek küçük azınlığın hizmetinde olanlar, kendilerini halka milliyetçi olarak yutturmaya baklyorlar. Bunların milliyetçilikle hiçbir ilişkisi yoktur. Gerçek milliyetçiler her türlü sömürüye karşı çıkan, yurdunun siyasi ve iktisadi bağımsızlı̆̆ını savunan emekçiler, emekten yana olan sosyalistlerdir."

Burada da görüleceği üzere TỉP milliyetçilik anlayışını Atatürk milliyetçiliği ile bağdaştırma çabası içerisine girmiştir. Yabancı sermayeye karşı bir “dış düşman” algısı yaratmaya çalışmış, diğer milliyetçi hareketleri de bu düşmanın hizmetinde olarak 
tanımlamıştır. Bu açıklaması da TIP'in toplumdaki milliyetçilik duygusunu kendi eksenine oturtma gayesi olarak yorumlanabilecektir.1965 yılında TIP kadrosunun radyo konuşmalarının derlendiği bir kitapta, genel başkan Mehmet Ali Aybar, Atatürk Milliyetçiliğii'ni şöyle tanımlamıştır (Aybar, 1964, s. 56):

"Atatürk milliyetçiliğine gelince; bu ilke ayırıcı ve başka milletleri küçük gören veya boyunduruk altına almayı amaç bilen ırkçı, şoven bir milliyetçilik anlayışı değildir. Atatürk birçok defa Türk milliyetçiliğini etnik unsurlar arasında bir ayrım gözetmeden ve bunların yurttaşlık haklarını kisıtlamadan tarif etmişstir. Türk milliyetçiliği milletin bütün fertlerini kaderde, klvançta ve tasada ortak bölünmez bir bütün olarak kabul ettiği için tam demokratik ve sosyal adaletçi bir kavramdır. Türk milliyetçiliği halkımızı dünya milletleri ailesinin eşit haklara sahip ve kişiliği olan bir üyesi haline getirmeyi bilimde, teknikte, kültürde ve sosyal hayatın her alanında daima yüceltmeyi amaç bilir."

Aynı kitapta TİP Ankara İl Başkanı ve Senatörü Niyazi Ağırnaslı da TİP'in milliyetçilik anlayışını açıklarken “Kullû müminün ihve” ayetine atıfta bulunarak İslam'ın bütün Müslümanları kardeş saydığını; ırkçılığa ve kafatasçılığa karşı olduğunu hatırlatmıştır. TİP'in de Misak-1 Milli sınırları içerisindeki emekçileri, çiftçileri, dar gelirlileri ve gençliği kardeş saflarında toplamaya davet ettiğini beyan etmiştir (Ağırnaslı, 1964, s. 22). TİP Genel Sekreteri ve Sendikacı Kemal Sülker 29 milyon Türk’ün kendi ana yurdunda kıvrım kıvrım kıvrandığını belirtmiştir (1963 yılında Türkiye nüfusu: 29,5 milyondur [Dünya Bankası, 2020]). Ayrıca ülkücü toplumcu aydınları da “Atatürk ülküsünü yaşatmak için ant içen” kimseler olarak tanımlamıştır (Sülker, 1964, s. 43). TİP Diyarbakır Belediye Başkan Adayı Tarık Ziya Ekinci de doğu bölgesindeki problemlere değinirken vatandaşlara "Doğulu kardeşlerim” olarak hitap etmiştir (Ekinci, 1964, s. 47). Buradaki ifadelerden hareketle, TİP'in, Türkiye'de yaşayan azınlıkların varlığını kabul etmediği ya da göz ardı ettiği yorumu yapılabilir. Ayrıca pragmatist tavırlarının bir göstergesi olarak İslamcı ve Ülkücü cenahın benimsediği söylemlere atıflarda bulundukları söylenebilecektir.

Nitekim Mehmet Ali Aybar, diğer sol hareketlerden farklı olarak parlamenter mücadele yolunu tercih etmiş; zaman zaman pragmatik davranmak zorunda kalmıştır. MDD tezlerine de itibar etmeyerek bütün emekçilerin partisi olma iddiasını gütmüştür. Bu nedenle de TİP, tüm üyeleri ve parti örgütünü disipline edecek katı bir ideoloji belirlememiştir. Parti'nin ideolojisinde istifa edene kadar Aybar etkili olmuştur (Yanık ve Bora, 2017, s. 280). TİP'in pragmatizmi bir ara öyle ileri gitmiştir ki bir ara neredeyse "dini siyasete alet etmekten" mahkemelik olma durumuna gelmiştir (Karpat, 2015, s. 235). 
Doğan Avcıŏlu ve Mihri Belli gibi isimlerin Sosyalizm, Marksizm ve Kemalizm’e bağlı Sosyalist Devrim ve Milli Demokratik Devrim tezlerini tartışmaya açmaları sonucu canlı bir tartışma ortamı doğmuştur. Bu süreçte TíP de bu tartışmalara dâhil olmuş ve sosyalist devrimciler, proleter devrimciler ve milli demokratik devrimciler ayrışmasını yaşamıştır. Parti yönetimi bu süreçte Sosyalist Devrim savunucusu olurken; parti içi muhalefet ise MDD tezini savunmuşlardır. Nihayetinde de Mihri Belli, Deniz Gezmiş, Mahir Çayan ve Doğu Perinçek gibi isimlerin de aralarında bulunduğu MDD savunucuları ya partiden atılmış ya da kendileri ayrılmışlardır. Partiden ayrılan muhalefet içinde yeni bir örgütlenme kurulması ve başına Mihri Belli'nin geçirilmesi fikrine Belli çekingen yaklaşınca MDD savunucuları da kendi aralarında ayrılmaya başlamışlardır (Bektaş, 2015, s. 322).

\section{Milli Demokratik Devrim (MDD) Hareketinde Milliyetçi Söylemler}

MDD, Türkiye İşçi Partisi'ndeki muhalif hareketin ayrılması sonucu Mihri Belli liderliğinde oluşmuştur. MDD, TİP’ten ayrılan binlerce kişiyi yeni bir çizgide toplayacak bir etkinlik gösterememiş; oldukça kısa ömürlü olmuş bir harekettir. Ancak yine de MDD’nin Türk solunun ideolojisi üzerindeki etkisi uzun yıllar boyu sürmüştür (Yurtsever, 2008, s. 90). MDD stratejisi, temel çelişkiyi kapitalist sınıflar ve emek arasında değil; emperyalizm ile ezilen uluslar arasında kuran, "Üçüncü Dünya”ya özgü bir stratejidir (Aydın, 1998, s. 60).

MDD'nin, reel sosyalizm deneyimi Sovyet tezlerinden ve TKP'nin politik hattından beslenmiştir ancak onun ayırıcı yönü millici ve doğucu nitelikleridir (Ayçiçek, 2020, s. 1045). Yurtsever'e (2008, s. 84) göre Kemalizm'in ve milliyetçiliğin MDD üzerindeki etkisi son derece açıktır. Devrimde orduya ve Kemalizm'e biçilen rol Marksizm'in bilimselliği ve ordu konusundaki fikirleri ile çelişmektedir. NATO'ya bağlı bir burjuva cumhuriyetinin ordusuna devrimci misyonlar yüklemek MDD’nin en temel yanlışlarındandır. Ancak Mihri Belli’ye göre Türk Ordusu, Çanakkale ve Kurtuluş savaşlarındaki antiemperyalist tavrın mirasçısıdır ve Amerikan emperyalizmi de bu şerefli orduyu kendisinin "halktan kopuk yaldızlı ordusuna" benzetmeye çalışmaktadır. Belli (2015, s. 249), Amerika'nın bütün çabasına rağmen Türk tarihinin ve milli geleneklerin ağır basacağına inanmaktadır.

MDD lideri Mihri Belli'ye göre en doğru strateji Türk tarihinde, kültüründe ve geleneklerinde olumlu olan şeylere sırt çeviren emperyalistlerle menfaat birliği sağlayanlara karşı milli bir güç birliği oluşturmaktır. Hatta Belli, TKP'nin çizgisini milli güçlere karşı provokasyona neden olmak ve onları küstürmekle suçlamıştır. Belli de, Yön hareketinden Avcıŏglu'ya benzer şekilde, Kemalist devrimin yarım kalmış bir anti-emperyalist milli demokratik bir devrim olduğunu düşünmektedir. Ona göre 1930’lu yıllardaki Türkiye sosyalizme 1960'l1 yıllardakinden daha yakındır. Belli, “asalak burjuvazinin titrek elinin” 
milliyetçilik bayrağını kavrayamayacağına inanmıştır. Bu nedenle de bu bayrağı sosyalistlerin ele alması gerekmektedir çünkü ona göre milli gurur insanları sosyalizme götürecektir. Emperyalistleri eleştirirken Belli, zaman zaman ırkçı bir çizgiye de kayarak "Elin gâvurları" tabirini de kullanmıştır. (akt. Bora, 2018, s. 654).

1967 yılında yayın hayatına başlayarak Milli Demokratik Devrim hareketinin sözcüsü konumuna gelen Türk Solu dergisi yazarlarından Suphi Karaman, derginin üçüncü sayısında milliyetçiliği tanımlamıştır. Ona göre, Atatürk döneminde milliyetçilik kavramının temel anlamı istiklaldir. Daha sonra da devrimlerin bir gerekçesi olmuştur ta ki Atatürk devrimleri hızını yitirene kadar. Bundan sonra ise milliyetçilik, Osmanlılıktan silkinemeyenlerin elinde 1rkçılığın ve dinciliğin eline düşmüştür. Atatürk’e hakaret edecek kadar ileriye giden gerici, dinci, ırkçı ve Anadolucu gibi isimler bir anti-Kemalist formda inşa ettikleri kimliklerine milliyetçilik demişlerdir. Karaman’a (1967, s. 2) göre gerçek milliyetçinin ilham kaynağı halkın yaşantısı ve yurdun gerçekleridir. Kim ki Türk toplumunun mutlu olmasını istiyorsa işte gerçek milliyetçi odur.

Yine aynı sayıda yazan Ağırnaslı da (1967, s. 5) Türkiye'ye kök salan emperyalistleri ve sömürü düzenini söküp atmak için milli bir duruş sergilenmesi gerektiğine inanmaktadır. Ona göre gerçek milliyetçiler, aydın ve devrimci gençler, Şerefli Türk ordusu, işçiler, meslek ve sanat kurumları, mezhep ve dil farkına bakılmaksızın bütün Türk halkı ve yurtsever siyasi partiler bu duruşta yer almalıdır.

Belli’ye (2015, s. 248) göre Anafartalar'daki Türk ve Dumlupınar'daki Türk için o günlerde tek bir mesele vardı: Yabancılar vatan toprağına saldırıyordu ve topraklar savunulmalıydı. Görüldüğü üzere MDD söylemleri sınıfsal taban ve analizler üzerine değil daha çok milli nitelikler üzerine inşa edilmiştir. Bunun sebebi de kitlesellik kazanmaya çalışmakla açıklanabilecektir (Aydın, 2008b, s. 544).

Türkiye'de milliyetçiliğin yerleşmesine karşı çıkanları eleştiren Belli (2015, s. 228), Türkiye halkının bir ulus payesine yükselmesi gerektiğini düşünmektedir. Ona göre bunu engelleyen kişiler kozmopolitçilik, ümmetçilik ve halifecilik gibi akımları kullanarak işbirlikçi sermaye ve feodal mütegallibe ile ulus düşmanlığı yapmaktadır. Bunlar çıkar birliği içindeki gayri-milli sınıflardır ve emperyalizmin koltuğunun altındadırlar. MDD de bu emperyalist, işbirlikçi ve sermaye-feodal mütegallibe ortaklıklarına karşı gerçekleştirilecektir. Çağın en büyük gerçekliğinin millet gerçeği olduğunu ileri süren Belli (1969, s. 24), millet olmanın içinde bulunulan dünyada ezilen halkların birinci davası olduğunu çünkü millet olmanın emperyalizmin boyunduruğunu kırdığını ve toplumlardaki bireyleri özgürleştirdiğini iddia 
etmiştir. Yani millet olmayı (uluslaşmayı) sosyalist toplum yolunda atılan bir adım olarak görmektedir çünkü millet olmak insanın insan tarafından sömürülmesini engellemiştir.

Üzerinde hassasiyetle durulması gereken konular olan millet ve milliyetçilik kavramlarının etrafındaki gayri milli güçler bertaraf edilmelidir çünkü eğer bu kavramların etrafını saran sis kaldırılmazsa bu değerli kavramlar emperyalistler ile işbirlikçilerine meydanı bırakacak; bu yüzden de birçok gencin sahte milliyetçilik sloganlarına kanmasına neden olacaktır. Bunun en temel örneği de "Tam Bă̆ımsız Türkiye” sloganına karşı ABD vesayeti tarafından üretilen “Milliyetçi Türkiye” sloganının çıkarılmasıdır (Belli, 1969, s. 25). Buradan hareketle Belli'nin bir diğer amacının da milliyetçilik gibi topluma nüfuz eden bir olguyu kontrol altında tutmak istediği olduğu varsayılabilecektir. "Gerçek Milliyetçiler" olarak tanımladığı kimselerin niteliklerini aşağıdaki gibi sıralamıştır (Belli, 1969, s. 26):

i. Kim toplumda hangi şahıs, çevre, sınıf ya da zümre katkıda bulunuyorsa, o gerçek milliyetçidir.

ii. Kim Türk dilinin gelişmesi uğrunda çaba harcıyorsa kim buna katkıda bulunuyorsa o en derin milliyetçidir.

iii. $\quad$ Kim Türkiye topră̆l üzerinde Türk halkının egemenliğine gölge düşüren durumlara karşı çıkıyorsa, örneğin kim toprağımızın bir parçasını kapsayan Amerikan üslerinin kaldırılması uğrunda mücadele ediyorsa milliyetçi olan odur.

iv. Kim Türkiye'nin feodal kalıntılarından arınarak iktisadi yaşantı birliğinin gerçeklemesi uğruna mücadele ediyorsa, örneğin kim köklü bir toprak reformu için çabaliyorsa gerçek milliyetçi odur.

v. Kim ulusal kültürle bağdaşmayan feodal kültüre karşı çıkıyorsa, kim kültürümüzü yozlaştıran, onu baltalayan batı kozmopolitizmine karşı mücadele ediyor, ulusal değerlerimizi olanca gücüyle savunuyorsa, kim ulusal edebiyata, ulusal müziğe vb. katkıda bulunuyorsa gerçek milliyetçi odur.

Belli'nin Sağ Milliyetçi görüşlere bir göndermede bulunarak, kendi fikir ve politik taleplerini milliyetçilik ile bağdaştırdığı gözlemlenmektedir. Yukarıda saydığı niteliklerde Amerikan üslerine ve toprak reformuna yaptığı atıflar bunun temel belirteçleridir. Ayrıca yine bu listeden çıkan bir sonuç da Belli'nin dil ve kültür odaklı bir milliyetçilik anlayışı olduğu yorumu yapılabilecektir. Ona göre Türkiye gibi birden çok etnik grubu içerisinde barındıran bir ülkede güdülen gerici kültür politikaları, kültürel baskı şeklinde kendini gösterir. Kürtler kardeşliğini tarih önünde ispatlamıştır ve Kürt halkının etnik varlığını reddeden faşizan bir 
politika halkın birlik ve beraberliğini baltalayarak düşmanların ekmeğine yağ sürmektedir (Belli, 2015, s. 207).

Millet ve vatan gibi kavramların ilk önce burjuva demokratik devrimlerinin sonucunda ortaya çıktığını söyleyen Belli (1969, s. 25-30); Engels’e atıf yaparak “milli bağımsızlık olmadan herhangi bir ülkede burjuvazinin egemenliği mümkün değildir” fikrini desteklemiştir. Belli “ulus, kapitalizmin şafak vakti ortaya çıktı, kapitalizmin gelişmesiyle de gelişti” fikrini de desteklemektedir. Ulusların bir irk topluluğu olduğuna ya da bir klanın genişlemesi ile vücut bulduğuna dair fikirlere katılmadığını söyleyen Belli; bu tezi çürütmek için Fransız, Amerikan ve Türk uluslarını örnek göstermiştir. Ulusun sosyalist literatürde "Tarihi olarak teşekkül etmiş istikrarlı insan topluluğudur ve şu dört karakter birliği esasına dayanır: Dil birliği, toprak birliği, iktisadi hayat birliği ve ulusal kültürde birlik içinde beliren ruhi şekillenme birliği”, olarak tanımlandığını belirtmiştir ve bu dört şartın ulus olma şartları olduğunu onaylamıştır. Belli’ye göre ulusların bir başlangıcı vardır ve bir de sonu olacaktır. Yine de uluslar gökten inmemişlerdir kökenleri çok eskilere dayanır ancak uluslaşma süreci Türkler için oldukça yakın bir geçmişte, 19. Yüzyılda olmuştur. Ancak örneğin Osmanlı toplumunda yaşayan diğer uluslar için ulus bilincinin gelişmesi süreci farklı zamanlarda yaşanmıştır.

MDD'den kopan gruplar Türkiye tarihinin en hareketli dönemlerinden birisinin yaşanmasına sebebiyet vermişlerdir. Bu gruplar: İbrahim Kaypakkaya’nın Türkiye Komünist Partisi-Marksist/Leninist (TKP-ML) ve onun askeri kolu Türkiye İşçi Köylü Kurtuluş Ordusu (TİKKO), Deniz Gezmiş'in Türkiye Halk Kurtuluş Ordusu (THKO) ve Mahir Çayan'ın Türkiye Halk Kurtuluş Partisi-Cephesi'dir. (THKP-C). Bu oluşumların değerlendirilirken söylemden ziyade eylemi ön planda tutan; yani pratiğin teoriden önce geldiği oluşumlar oldukları unutulmamalıdır (Yurtseven, 2008, s. 106). Nitekim bu gruplar Türkiye'de bir terör mücadelesi veya kent gerilla savaşlarını başlatmışlardır (Zürcher, 2020, s. 294).

\section{Proleter Devrimci Aydınlıkçılarda Milliyetçi Söylemler}

TİP ve MDD hareketlerinden sonra üniversite gençliği için bir sonraki durak Fikir Kulüpleri; ardından da bu oluşumların üst yapısı olan Fikir Kulüpleri Federasyonu (FKF) olmuştur. FKF ilk kurultayına giderken MDD-SD ayrımının birer yansıması olarak içeride ayrılıklar ve muhalif sesler yükselmeye başlamıştır. İkinci kurultayında da TïP ve Mehmet Ali Aybar tarafindan bizzat desteklenen bir aday olan Doğu Perinçek, FKF'nin lideri olmuştur. MDD tezlerinin savunucusu olan Perinçek'in başa gelmesi ile birlikte FKF içerisindeki SDMDD tartışmaları şiddetini artırmıştır. Ayrıca Perinçek yönetimindeki FKF, Devrimci Güçbirliği Platformu'na (DEV-GÜÇ) katılmış ve bu nedenle de TİP ile arasında gerilimler başlamıştır. Üçüncü kongrede Perinçek'in başkanlıktan düşürülmesi ve Zülküf Şahin'in başkan 
seçilmesi ile FKF, DEV-GÜÇ’ten ayrılmıştır. Yusuf Küpeli'ye göre Perinçek "geldiği gibi gitmiştir." 60'lı yılların sonuna gelinirken de FKF yönetimini büyük oranda ele geçiren grup FKF’yi tasfiye etmiş ve Türkiye Devrimci Gençlik Federasyonu'nu (DEV-GENÇ) kurmuşlardır. FKF, DEV-GENÇ ve MDD içerisinde de kendini gösteren ayrılıklar Aydınlık Sosyalist Dergi'de de (ASD) kendini göstermiş; bu tartışmalarda da en çok Mahir Çayan ve Doğu Perinçek yer almışlardır. Çayan tarafından sağa sapmakla suçlanan ve ASD içinde istenmeyen konuma düşen Perinçek ve grubu da dergiden ayrılmışlardır (Odabaşı, 2017, s. 341$358)$.

Çıkardıkları dergiye atfen Proleter Devrimci Aydınlıkçılar (PDA'cılar) olarak tanımlanan bu grubun lideri Doğu Perinçek’tir. PDA hareketi aslında 1974 yılından sonra bir milli çizgiye oturmaya başlamıştır. PDA'cılar, diğer Maocu hareketler ile Kemalizmin yorumlanması bakımından tartışmalara girmeye başlamış; bir süre sonra Kemalizm'e sosyalist açıdan bakan değil; sosyalizme Kemalist açıdan bakar bir hal almışlardır. Sosyalistleri milliyetçiliğe taşıma çabalarının başlangıç noktası anti-emperyalizm vurgusudur ancak bu vurgu ileride giderek anti-Sovyet bir biçime evrilmiştir. Anti-Sovyet söylemlerinde dönemin sağ milliyetçileri ile söylem birliğine varacak kadar radikal bir tutum takınmışlardır. Sovyetler yıkıldıktan sonra da Kemalizm'in ulus-devletçi, milli birlikçi, anti-İslam ve anti-Kürt tutumlarını devralarak Kemalizm'in sivil siyasetteki aktivistleri olmuşlardır (Aydın, 2008a, ss. 474-475).

Aslında Perinçek, Kemalizm'in en büyük savunucularından olarak görünse de, yer yer Kemalizm'e en ağır eleştirileri yapmıştır. Perinçek'in Kemalizm'e bakışı 1970'lerin sonlarında daha ılımlı bir hal almıştır. Kemalizm'i tamamen bir burjuva ideolojisi olarak gören Perinçek’e göre Kemalistlerin liderlik ettikleri Kurtuluş Savaşı halkın devrimci tarihinin bir parçasıdır ve bu devrimci miras savunulmalıdır (Yardımoğlu, 2015, s. 44). Yine aynı şekilde Perinçek'in ideolojisindeki milliyetçiliğin baskınlığı da 1970'lerin ortasından itibaren belirginleşmiş; 80 ve 90’lı yıllarda Perinçek ve milliyetçilik arasındaki bağ git gide güçlenmiştir (Erten, 2008, s. 464466). 2000'li yıllardan sonra ise Perinçek artık bir milliyetçidir. Ancak bu çalışmanın amacı gereği Perinçek'in ve PDA'nın 1960'ların sonu ve 1970'lerin başlarındaki söylemleri ele alınacaktır.

1960’ların sonunda Mülkiye’deki asistanlığı sırasında Fikir Kulüpleri Federasyonu’nun (FKF) başkanı olarak siyaset sahnesine çıkan Perinçek'in siyasal çizgisinin "milliyetçi bir sol" olarak değil; "sol bir milliyetçi" olarak tanımlanması ve buradaki milliyetçi kelimesinin de altının çizilmesi gerekmektedir (Erten, 2008, s. 463). Milliyetçilik tonu bir hayli yüksek olan 
Perinçek, ulus devletlerin kalkınmacılık arayışlarını da sosyalizme dâhil olarak kabul etmektedir (Ünüvar, 2008, s. 711).

1960’lı yılların sonu ve 1970'li yılların başlarında Perinçek ve partisi, proleter enternasyonalizm savunucusu konumundadır ve milliyetçiliğin bir burjuva ideolojisi olduğunu savunmaktadır. Hatta MDD hareketindeki ayrılma Perinçek'in milliyetçilik söylemlerine karşı geliştirdiği bir tavırlar sonucu gerçekleşmiştir. Milliyetçi devrimcilik Perinçek’e göre proleter enternasyonalizmin reddi demektir ve burjuva milliyetçiliği de emperyalizme boyun eğilmesi anlamina gelmektedir (PDA, 1970, s. 263)

Perinçek’e göre “bizler, uluslararası tekelci sermayenin ve yerli ortaklarının baskı ve sömürüsü altında yaşayan bir halkın çocuklarıyızdır’. İşte bu hâkim sınıflar ise sosyalizmin halk kitlelerine ulaşmasını engellemek için ellerinden geleni yapmaktadırlar. Bunu ise ya baskı, terör gibi eylemlerle ya da halkı gerici ideolojilere hapsetmek yoluyla gerçekleştirmektedirler. Marksist ve Leninist öğretinin halk tarafından öğrenilmesine en büyük karşı saldırı ise Milliyetçilik bayrağı altında yapılmaktadır. Bu fikirdeki insanlar Lenin, Marx, Stalin, Engels ve Mao gibi büyük fikir adamlarının devrimci teorilerinin Türk damgasını taşımadıkları için reddedilmesini istemektedirler. Bu büyük fikirleri Türk olmadığı için reddeden söz konusu milliyetçi cenah, ülkenin yabancı sermaye altında kalması için ise elinden geleni yapmıştır. Çünkü bu milliyetçilik anlayışı işbirlikçi burjuvazinin yaymış olduğu "gerici milliyetçiliktir". $\mathrm{Bu}$ milliyetçi akımın yanında sosyal demokrat, oportünist ve revizyonist diğer akımlar da bilimsel sosyalizme saldırmışlardır. Sosyal Demokratlar, Kemalizm’den başka ideolojiye ihtiyaç duyulmadığını; oportünistler "Türkiye’ye özgü sosyalizm” teorisini ve revizyonistler de (Burada ASD kastediliyor) Marksizm ve Leninizm'i aynı zamanda bir "devrimci Milliyetçilik”, olarak anlatmaya çalışarak proleter devrimci mücadeleye karşı bir burjuva muhalefeti yürütmüşlerdir (Perinçek, 1970b, s. 479).

Perinçek’e (1970b, s. 481) göre tarihimizde nasıl ki Fransız İhtilali’nin demokratik fikirleri ve matbaa "gâvur icadl" diye Türkiye'ye sokulmadıysa Marksizm-Leninizm için de aynı politika izlenmektedir. Bu ideolojilere gâvur icadı damgası yapıştırılmak için de milliyetçilere sırt dayanmaktadır, yani "gerici milliyetçi” cenahtan destek alınmaktadır. Ancak nasıl ki ampulü kullanırken Edison'un milliyetine bakılmıyorsa, Marksizm-Leninizm ve Mao düşüncesi kullanılırken de bakılmamalıdır. Bu nedenle de evrensel ideolojiler olan MarksizmLeninizm-Mao düşüncelerini bir coğrafya teorisi ile eklemlemeye çalışmak ancak bir burjuva düşüncesinin eseri olabilir (Perinçek, 1970b, s. 89).

Sovyetler Birliği’ni Türk Hükümeti ile yakın ilişkiler kurduğu için eleştiren Perinçek’e (1970b, s. 490) göre Sovyetler'in Türkiye'de giriştiği hareketler işbirlikçi burjuvazinin 
menfaatinedir. Hatta Perinçek “ortanın solu” propagandasını da bu yakınlaşma ile anlamlandırmaktadır. Kurtuluş Savaşı'nda Türklere yardım eden Sovyetler'de proleterya ve Lenin iktidarda iken, bugün yardım eden Sovyetler'de ise tekelci bürokrat-kapitalist revizyonistler iktidardadır. Ayrıca Perinçek (1970a, s. 237), PDA'da yazdığı bir yazısında Bülent Ecevit'in Kemalist kökleri, Kemalist geleneği; yani devrimci olan her şeyi reddetmekle suçlamış ve Ecevit'in Mustafa Kemal'i faşist olarak değerlendirdiğini iddia etmiştir. CHP, ortanın solu ve Ecevit, emperyalizm ve işbirlikçilerinin hapsi altına alınmıştır.

Sosyalizm ve milliyetçiliğin kesinlikle tutarsız olduğunu söyleyen Perinçek’e (1970b, s. 493) göre sosyalizm milletleri yok etmeye çalışmaktadır. Bu açıdan da dönemin milliyetçisosyalist söylemlerini eleştirmiştir. Milliyetçilik bir burjuva ideolojisidir ve emperyalizmin bölparçala-yönet politikasına hizmet etmektedir. Milliyetçi davranışlar teşvik edilerek işçi dayanışması engellenmeye çalışılır. Proleterya milliyetçi değildir ancak yurtseverdir ve enternasyonalisttir. Anavatanın ve halkın her türlü yabancı saldırıdan korunmasında en tutarlı ve fedakâr sınıftır ve mücadelenin önderidir. Ancak milliyetçiliğin tarih boyunca kazandığ içerik tehlikelidir ve milliyetçi düşünce ile mücadele edilmelidir.

Yukarıda da söylendiği gibi, Perinçek'in milliyetçiliğe karşı tutumu dönemsel olarak farklılık göstermektedir. Bilhassa 2000'li yıllardan sonra Perinçek için milliyetçilik ağır basmaktadır. Ancak bu çalışmanın amacı gereği Perinçek'in ve PDA'nın 1960'ların sonu ve 1970’lerin başlarındaki söylemleri ele alınmıştır.

\section{Türkiye Halk Kurtuluş Ordusu'nda (THKO) Milliyetçi Söylemler}

THKO, Deniz Gezmiş'in liderliği ile bütünleştirilmiş bir örgüttür. Bunda onun örgütte ön plana çıkmasının yanı sıra Gezmiş’in Kemalist ve milliyetçi çizgideki eylem ve söylemlerinin de etkisi vardır. Nitekim kendisi 1968 yılında Samsun'dan Anıtkabir'e düzenlenen Mustafa Kemal yürüyüşüne öncülük etmiş, babasına yazdığı mektuplarda "ikinci Kurtuluş Savaşı” ifadelerini kullanmıştır. Ayrıca bu kadro kendisine "ikinci Kuvayı Milliye”, adını vermiştir. Mustafa Kemal yürüyüşü ile Anıtkabir'e ulaşan Gezmiş ve arkadaşlarının Anıtkabir defterine yazdıkları satırlar manidardır: "Milli kurtuluş yolunda, Amerikan emperyalizmine karşı gerçekten izindeyiz. Milli kurtuluş mücadelesi yok edilemez, onu yok etmek için bütün Türk milletini yok etmek gerekir.” (akt. Atılgan, 2017, s. 329-330).

THKO’nun ideolojik çerçevesini dizayn eden, Deniz Gezmiş ve Yusuf Aslan ile birlikte idam edilmiş olan Hüseyin İnan'dır. Dönemin Kürt asıllı (Bayrak, t.y.) aktivistlerinden olan İnan, MDD’den ayrıldıktan sonra THKO saflarına geçmiş; 1972 yılında da idam edilmiştir. İnan'a göre Kurtuluş Savaşı'na Türkiye'deki bütün ulusların anti-emperyalist sınıfları katılmış ancak bağımsızlıktan sonra Türk milliyetçilerinin hâkim olduğu hükümet Türk ulusunu 
imtiyazlı hale getirerek hiçbir ulusa demokratik haklar tanımamıştır. Bu da kimi zaman asimilasyon, sömürü, terör ve iktisadi baskı olarak kendini göstermiştir. Ancak ABD emperyalizminden bütün halk zarar görmüştür ve görmektedir. Bu nedenle de tüm uluslar bir Türkiye Halkı olarak emperyalizmi kovmalıdır. Emperyalizm kovulduktan sonra ortaya çıkacak olan demokratik halk idaresinde bütün uluslar hak ve özgürlüklerini sağlayacaklardır (İnan, 2015, s. 445).

THKO'nun Kürt meselesine bakış açısı Gezmiş ve İnan'ın söylemlerinden analiz edilebilmektedir. Gezmiş idamından evvel babasına yazdığı mektupta “... Sadece senin değil, Türkiye'de yaşayan Türk ve Kürt halklarının da beni anlayacağına inanıyorum... ” şeklinde bir ifade kullanmıştır (akt. Behram, 2001, . 50). Ayrıca darağacına çıktığında söylediği son sözlerinden bir kısım ise “...Yaşasın Türk ve Kürt Halklarının bă̆ımsızlık mücadelesi...” şeklindedir. Hüseyin İnan da ulusların kendi kaderlerini tayin hakkı ilkesine saygı gösterdiklerini belirtmiştir ancak ona göre Kürt emekçilerinin çıkarları ancak Türkiye halkının ortak mücadelesi ile sağlanabilecektir. Bu nedenle Türkiye'nin toprak bütünlüğü bütün emekçi sınıfların faydasınadır. Doğu ve güneydoğuda ayrılıkçı bir politika izlenirse, Kürt burjuvası Kürt emekçileri üzerindeki hâkimiyetini devam ettirecektir. Kurulacak olan devlette burjuvanın milliyetçiliği hâkim olacak; Kürt ulusu ile diğer tüm ulusların arasına bir duvar örülecektir. Bu duvar da emekçi sınıflar arasında bir engel oluşturacaktır. Bu nedenle ayrılıkçı politikaya karşı el birliği ile mücadele edilmeli ve her zaman Türkiye proleteryasının çıkarları öncelik olmalıdır. Türkiye emekçilerinin çıkarlarına en uygun yöntem bölgesel özerkliktir (İnan, 2015, ss. 446447).

\section{Türkiye Halk Kurtuluş Partisi-Cephesi'nde (THKP-C) Milliyetçi Söylemler}

MDD'den ayrılarak THKP-C saflarına geçen Çayan, MDD hareketini, Aydınlık Sosyalist Dergi'yi ve Türk Solu Dergisi’ni “dönemini kapatmış” olarak yorumlamış ve sağc1 ideolojiye teslim olduklarını iddia etmiştir. Baştan beri Belli ile görüş ayrılıkları olduğunu ancak buna rağmen Belli'ye yüksek oranda tolerans gösterdiklerini belirten Çayan, Belli'nin milliyetçi ve revizyonist fikirlerini düzeltme yoluna gittiğini söylediğini ancak zamanla bu söyleminde samimi olmadığını anladıklarını söylemiştir. 29-30 Ekim tarihli toplantıda Çayan, Belli’nin terk ettiğini ima ettiği eski sağ görüşlerini tekrar ileri sürdüğünü söylemiş ve Belli’yi bölücülükle suçlamıştır (Çayan, 2015, ss. 336-337).

Çayan (2015, ss. 357-358), Mihri Belli'nin milliyetçilik fikirlerini şiddetle eleştirmiş ve sosyalistlerin milliyetçi değil yurtsever olduklarını Belli’ye hatırlatmıştır. Belli'nin küçük burjuva radikalizmine bel bağlamasından dolayı milliyetçilik fikirlerini şirin görünmek için bilinçli olarak savunduğunu iddia etmiştir. Belli’nin Kürt haklarının Misak-1 Milli sınırları 
içinde ele alınması gerekliliği fikrini de anti-sosyalist bulan Çayan, ulusların kendi kaderlerini tayin hakları 1şığında ele aldığını söyleyerek özerklik ya da federasyon gibi bir çözüm yolu düşünülebileceğini söylemiştir. Çayan'a göre ayrılıkçı bir Kürt politikası da Kürt küçükburjuva milliyetçilerinin görüşleridir.

Çayan'a göre Mustafa Kemal bir “küçük burjuva” ve Kemalizm de küçük burjuvazinin en radikal, antiemperyalist, milliyetçi ve sol ideolojisidir (Yurtsever, 2008, s. 126) . Tüm fikir ayrılıklarına rağmen Çayan, Ergun Aydınoğlu'na göre “tüm eklektik teorik rötuşlarına rağmen MDD perspektifinden çıkamamıştır." (Aydınoğlu'ndan akt. Bora, 2018, s. 659).

\section{Türkiye Komünist Partisi-Marksist/Leninist Örgütlenmede Milliyetçi Söylemler}

MDD'den ayrılanların en radikali, TKP-ML ve TİKKO'nun kurucularından olan İbrahim Kaypakkaya (2015, s. 493), Mihri Belli’yi ve kendi tabiriyle “Mihriciliği” azgın bir hâkim ulus milliyetçiliği olarak tanımlamıştır. Hatta Kaypakkaya (2015, s. 505), Lenin'e atıf yaparak Doğan Avcıŏlu, Bülent Ecevit, Mihri Belli ve Hikmet Kıvılcımlı'yı "bir elini demokrasiye öbür elini gericilere ve polis ajanlarına uzatan ikiyüzlü bezirgânlar” olarak değerlendirmiştir.

Avcıoğlu ve takipçilerini “kaba şovenist” olarak tanımlayan Kaypakkaya (2015, s. 506), Belli ve takipçilerini daha gizli ama yine de aşikâr bir Türk milliyetçisi olarak tanımlamıştır. Belli ve grubunu bazen “Türkeş'in ırkçı-Turancı Faşizmine” bile olumlu bakarken Kürt meselesine her daim olumsuz bakmasını eleştirmiştir. Ayrıca Belli'nin "milliyetçilik bayră̆ını taşımanın sosyalistlerin tarihi görevi” söylemlerine şiddetle karşı çıkmaktadır. Kaypakkaya'ya göre bu grup sözde milletlerin eşitliğini savunmaktadırlar ancak gerçekte devlet kurma hakkını sadece Türklere tanıyarak Kürtlerin devlet kurma hakkının birlik ve bütünlüğe zarar vereceğini iddia ederek demagoji yapmaktadırlar. Ancak komünistlerin devlet kurma imtiyazının sadece Türklerde olmasını kesinlikle savunmadığını, Kürtlerin devlet kurma haklarını da var güçleriyle savunacaklarını beyan etmiştir. Stalin'e atıf yaparak milleti dil, yaşanan toprak, iktisadi yaşam ve ruhi şekillenmede birlik olma ekseninde tanımlayan Kaypakkaya'ya (2015, s. 494) göre halk belirli bir dönemde ortaya çıkan ve sonra da yok olacak olan bir olgu değildir ancak millet kapitalizmle birlikte ortaya çıkmıştır ve sosyalizmin ileri bir safhasında da yok olacaktır.

Kaypakkaya'nın ideolojik ayrılışının temelinde Kemalizm eleştirilerinin köktenliği yatmaktadır. Ona göre Kurtuluş Savaşı anti-emperyalist bir hareket değil; tam aksine Asya halklarındaki burjuva ve egemen sınıflar için bir model niteliğindedir. Kemalizm hiçbir zaman yozlaşmamış; zaten en başından faşist başlamıştır, faşist bir diktatörlüktür ve sadece Kürtlere değil bütün azınlık milliyetlere bask yapmaktadır (Bora, 2018, s. 662). Hatta Kaypakkaya'ya 
(2016d, s. 542) göre, Mustafa Kemal'in bütün hayatı Kürt Milletine ve diğer azınlıktaki milletlere baskllar ve zulümlerle doludur. Kürtleri ve tüm azınlıkları zorla Türkleştirmeye çalışmış; bütün haklarını gasp etmiştir (Kaypakkaya, 2016c, s. 371).

Kaypakkaya (2016a, s. 267), Kürt Milleti’nin ayrılması konusunu milliyet fark etmeksizin sınıf bilinçli her proletaryanın desteklemesi gerektiğini söyleyerek şöyle demiştir: “Hangi milliyetten olursa olsun, sınıf bilinçli Türkiye proletaryası, Kürt milletinin ayrı bir devlet kurması meselesine devrimin gelişmesi, güçlenmesi açısından bakar. Ĕger Kürt milletinin ayrı bir devlet kurması, Türkiye Kürdistan'ında proletarya önderliğinde demokratik halk devriminin gelişmesi ve başarıya ulaşması imkânını artıracaksa, hangi milliyetten olursa olsun, sınıf bilinçli Türkiye proletaryası bizzat ayrllmayı destekleyecektir. Ĕger ayrılma, Türkiye Kürdistan'ında proletarya önderliğinde demokratik halk devriminin gelişmesini ve başarıya ulaşmasını geciktirecekse, zorlaştıracaksa, hangi milliyetten olursa olsun, sınıf bilinçli Türkiye proletaryası ayrılmayı desteklemeyecektir”.

Kürt devleti kurulması konusunda bölücülük demagojisi yapanları Kaypakkaya (2016a, s. 271) şöyle eleştirmiştir: "Bunlar ne pahasına olursa olsun, devletin ve toprakların bölünmemesinden, birliğinden yanadırlar! Yani Kürt milletinin ve bütün azınlık milliyetlerin zorla Türkiye Devleti sınırları içinde tutulmasından yanadırlar. Komünistler ise böyle bir "birliğe" karşıdır; komünistler her milliyetten işçilerin ve emekçilerin birliğini savunurlar. Toprakların ayrılmamasını veya bir tek devlet halinde örgütlenmeyi devrimin menfaatleriyle bağdaştığı zaman savunurlar (ve bunu savunurken bile, esas olarak işçilerin ve emekçilerin birliğini hedef alırlar); bağdaşmadı̆̆ zaman ise, toprakların ve devletin bölünmesini, ayrılmasını savunurlar. "Toprakların birliği" veya "devletin birliği” şiarı, hâkim ulusun burjuvalarının ve toprak ăgalarının şiarıdır.”.

Kaypakkaya (2016b, s. 330), Kürtler'den bahsedilirken “Kürt Milleti” yerine "Kürt Halkl " tabirinin kullanmasını eleştirmektedir. Çünkü ona göre halkların kendi kaderlerini tayin hakları "o halkın devrim yapma hakkl" anlamına gelmektedir. Ancak milletlerin kendi kaderlerini tayin hakları ise "o milletin ayr bir devlet kurma hakk»" anlamına gelmektedir. Halkın kendi kaderini tayin hakkı demek, hâkim milletlerin devlet kurma ayrıcalıklarını savunmak demektir.

Yukarıda değinilen Kaypakkaya'nın ifadelerinden bariz bir şekilde Kürt Milliyetçiliği yaptığı gözlemlenebilecektir. Yani Kaypakkaya da enternasyonal çizginin oldukça uzağındadır. Onun bu noktadaki amacı da fikirlerine ve TKP-ML'ye Kürtlerden bir kitlesel destek alma isteği olarak yorumlanabilir. Ya da bağımsız bir Kürt Devleti kurma hedefi için sosyalist ve 
komünistlerden bir kitlesel destek alma çabası olarak değerlendirilebilir. Hülasa, Kaypakkaya'nın tek amacının Marksist-Leninist fikirleri yaymak olmadığı aşikârdır.

\section{Tartışma ve Sonuç}

Türkiye Cumhuriyeti, emperyalist güçlere karşı verilen çok çetin bir mücadelenin ardından büyük zorluklar ile kurulmuş bir devlettir. Kurtuluş Savaşı esnasında toplumdaki dini, etnik ve ideolojik farklılıklar bir kenara bırakılmış ve yekpare bir halde vatan müdafaası için mücadele edilmiştir. Cephede kazanılan savaşların ardından yeni modern devleti inşa süreci hem Osmanlı'nın son dönemindeki savaşların hem de Kurtuluş Savaşı'nın karizmatik lideri Mustafa Kemal Atatürk'ün öncülüğünde başlatılmıştır.

1960’l1 yıllarda sahneye çıkan sol akımlardan ilki Yön dergisi ve Doğan Avcığlu etrafinda gelişen harekettir. Yön zaten fikirsel olarak Kemalizm ve Sosyalizm'i ortak bir potada harmanlamak için ortaya çıkmıştır. Bu nedenle de sosyalizmin temel argümanları olan sınıf çatışmaları ya da proleterya diktatörlüğü gibi kavramlar yerine Kemalizm'in milliyetçi ve halkçı kavramlarını ele almıştır. Gerçek milliyetçiliğin antiemperyalist bir tavırla kapitalizme karşı durmak olduğuna inanmaktadırlar. Kuvay-1 Milliye Ruhu'nu sosyalizmle ele almışlar ve sosyalizm kelimesi yerine de sol milliyetçilik gibi kavramlar kullanmayı tercih etmişlerdir. Bu da halkta bir sempati ve meşruiyet sağlama çabası olarak yorumlanabilir. Ancak Yön'ün milliyetçi söylemlerini sadece meşruiyet kazanma çabası olarak nitelendirmek büyük haksızlık olacaktır.

Yön, milliyetçi söylemlerini dile getirmekten geri durmamış hatta kimi zaman bazı çevreler tarafından ırkçılık veya sağcılıkla suçlanmaktan bile çekinmemişlerdir. Fakat sosyalist söylemler konusunda aynı özgüveni göstermemişlerdir. Nitekim Yön'de sağlam bir antikomünizm duruşu vardır; onlara göre komünizm bir kızıl tehlikedir. Türkiye'ye uygun gördükleri sosyalist sistemin (Türk Sosyalizmi) ilkeleri incelendiğinde de Kemalizm'in altı ilkesinin etkilerinin yüksek olduğu görülmektedir.

Yön'ün milliyetçiliği ele alışı kendi tabirlerine göre "Mustafa Kemal'in anladığ manada” bir milliyetçiliktir. Bu da dil, tarih ve kültür birliğine dayanmaktadır. Ayrıca Yön'ün milliyetçiliği saldırganlığa ve istilacılığa da karşıdır. Sağ milliyetçileri de ırkçı, faşist, şoven ve gerici olarak nitelendirmişler ve buna da kara tehlike adını vermişlerdir. Gerçek milliyetçilerin görevlerini de belirleyen Yön'e göre ülkenin menfaatleri için çözüm aramak her şeyden önce gelmelidir. Mesele de zaten sosyalizm değil; kalkınmayı sağlamaktır.

Yön'cüler Türkiye'deki grupların etnik farklılıklarına değinmemiş; bir dil, tarih ve kültür birliğinin sağlanması gerekliliğini vurgulamışlardır. Nitekim Türkiye'de yaşayan halkları tek bir ulus olarak ele almışlar ve bir dil, kültür ve tarih birliği oluşturulması 
gerekliliğini savunmuşlardır. Ulusun emperyalist güçler tarafından sürekli tehdit altında olduğuna inanmışlardır. Yön hareketi, sınıfsal söylemleri ön planda tuttuğu için TíP’i eleştirmiş ve toplumu böldüğünü iddia etmişlerdir. Bu açıdan bakıldığı zaman da Yön hareketini tam olarak sosyalist bir hareket olarak nitelendirmek doğru olmayacaktır.

Siyasal arenada mücadele yöntemini parlamentodan yana kullanan Türkiye İşçi Partisi, özellikle Mehmet Ali Aybar döneminde pragmatik bir yaklaşım izlemiştir demek yanlış olmayacaktır. Nitekim TİP bu politikasının meyvesini almış, dönemde uygulanan seçim sisteminin de yardımıyla, 1965 seçimlerinde TBMM'ye toplam 15 milletvekili gönderebilmiştir. TỉP de dönemdeki sol akımlara uygun olarak Kemalizm ile ilişkilenmiş ve antiemperyalist vurguları sıkça tekrarlamıştır. TİP’te sosyalizmin temel argümanı olan sınıfsal söylem Yön'e göre barizdir. Ancak TïP sınıf söylemini de milliyetçilik bağlamları ile harmanlamıştır. Sosyalizme en yakın sol hareket olarak nitelendirilebilecek olan TİP'in bilimsel ve teorik tutarlılığı, kendisini Kemalizm ile ilişkilendirme çabaları nedeniyle kaybedilmiştir. Emperyalizmin ABD'den veya Sovyetlerden gelebileceği düşüncesinde oldukları için anti-Sovyet bir tavır takındıkları da gözlemlenebilmektedir. TïP'e göre gerçek milliyetçilik, Türk ulusunun içte ve dişta sömürülmesini engellemektir.

Aybar'ın milliyetçilik söylemleri zamanla artmış ve bir süre sonra da diğer sol akımlar tarafından sağa sapmakla, burjuvalıkla ve popülizmle suçlanmıştır. Bu aslında TíP'in kendisine bir meşruiyet sağlamak için gösterdiği çaba olarak yorumlanabilir. Hatta bu çabayı çok ileri götüren TİP “dini siyasete alet etmek” suçundan mahkemelik olacak kıvama bile gelmiştir. Nitekim TİP, kendi solculuklarının dünya solculuğundan farklı olduğunu vurgulayarak arkasında kitlesel bir destek sağlamaya çalışmıştır. Çünkü TİP’in varlığı kazanabildiği destek miktarına bağlıdır. Bu nedenle de TİP'in pragmatist davranışlarının yadırganması çok doğru bir yaklaşım olmayacaktır.

TİP'e göre Türk milliyetçiliği halkın yabancı boyunduruğuna, sömürgeciliğine ve sömürücülüğüne karşı bir tepkisinden doğmuş ideolojidir, asla yayılmacı, sömürgeci ve başka milletleri aşağı gören bir milliyetçilik değildir. Nitekim kendileri de milliyetçilik anlayışlarını tanımlarken antiemperyalist ve halkçı milliyetçilik ifadelerini kullanmışlardır. "Türk" tanımları incelendiğinde ise, Türk Devleti'ne yurttaşlık bağı ile bağlı olan herkesi ırk, dil, din ve mezhep farkı gözetmeksizin Türk kabul ettikleri görülmektedir. Nitekim Kürtler hakkındaki beyanlarında Kürt ifadesi yerine doğulu kardeşler ifadesini tercih ettikleri gözlemlenmektedir. $\mathrm{Bu}$ açıdan ele alındığında Türkiye devleti sınırlarında yaşayan etnik grupların farklılıklarını kabul etmedikleri; homojen bir ulus beklentilerinin olduğu gözlemlenmektedir. Söylemlerinde toplumsal sınıfa ve ortak mülkiyete yaptıkları vurgular neticesinde de Yön'e göre nispeten daha 
sosyalist bir çizgide oldukları söylenebilse de, enternasyonalizmden oldukça uzak bir duruşları vardir.

Milliyetçilik ve Kemalizm etkilerinin aşikâr olduğu MDD düşüncesi Sovyet tezlerinden ve TKP'den besleniyor olsa da, millicilik ve doğuluk nitelikleri dolayısıyla farklılaşmaktadır. MDD hareketi oldukça kısa ömürlü olmuş ve içerisinden çok farklı gruplar meydana gelmiştir. MDD her ne kadar Türk Solu'na doğrudan ideolojik bir katkı yapmamış olsa da Türk Solu üzerindeki etkisi çok fazladır. MDD hareketinin söylemlerinde Türk milliyetçiliği vurgusu oldukça fazladır. Hatta bazen diğer ulusları "elin gâvuru" olarak nitelendirecek derecede dışlayıcı ve 1rkçı bir çizgiye de kaymıştır. MDD’ye göre gerçek milliyetçi toplumun mutlu olmasını isteyen kişidir. Milliyetçilik söylemleri yine antiemperyalist bir bağlamda gelişmiştir. Dış tehditlerin de yoğun olarak kullanıldığı bu söylemlerde Kürt halkının varlığı da tanınmaktadır. Hatta Kürt halkının etnik varlığını reddetmeyi faşistlik olarak değerlendirmektedirler. Kürtlerin etnik farklılı̆̆ını kabul ediyor olsalar da, milliyetçi tanımlarında “Türkiye topră̆ı üzerinde Türk halkı” egemenliği ifadelerini kullanmışlardır.

Millet ve milliyetçilik kavramlarının üzerinde önemle duran MDD’ye göre çağın en büyük gerçeği milletlerdir. Milletleşmek bireyleri özgürleştirdiği ve emperyalizmin boyunduruğunu kırdığı için sosyalizmin ilk aşamasıdır. Yani milletlerin bir başlangıçları vardır ve sonları da olacaktır. Ancak MDD’ye göre milletlerin kökenleri çok eskilere dayanmaktadır, milliyetçilik ise 19. Yüzyılın bir ürünüdür. Millet olmak için gerekli olan şartlar ise dil, toprak, ulusal kültür ve iktisadi hayat birliğidir. MDD hareketinin söylemleri yorumlandığında enternasyonalizmden oldukça uzak bir çizgide oldukları gözlemlenebilecektir.

Doğu Perinçek bugün her ne kadar milliyetçi ve Kemalist söylemleri ile bağdaşlaştırılmış ulusalcı bir lider olsa da; Perinçek'in 1970'li yıllardan önceki tutumları farklılık göstermektedir. Nitekim Perinçek, MDD’nin milliyetçi söylemlerine karşı geliştirdiği muhalefet hareketi sonucu MDD'den ayrılarak PDA'yı kurmuştur. PDA'ya göre milliyetçilik, Marksist-Leninist enternasyonalin reddi anlamına gelmektedir ve bu da burjuvaya ve emperyalizme boyun eğilmesi demektir. Milliyetçi söylemler altında sosyalizmin ülkeye yayılması engellenmektedir. PDA bu konu hakkında sağ milliyetçileri olduğu kadar sol milliyetçileri de eleştirmektedir. Çünkü onlara göre milliyetçilik bir burjuva ideolojisidir ve emperyalizmin böl-parçala-yönet ideolojisine hizmet etmektedir. Bu açıdan da sosyalizm ile tutarsızdır. PDA'nın milliyetçi olmadığı ve milliyetçiliği şiddetle reddettiği de aşikârdır. PDA hareketinin, diğer hareketlere göre sosyalizme ve enternasyonalizme en yakın konumda olduğu yorumu yapılabilecektir. 
THKO, fikirsel bir akım olmaktan ziyade eylem odaklı bir hareket olsa da, milliyetçi eylem ve söylemleri gözlemlenebilmektedir. Mustafa Kemal Yürüyüşü, kendilerini ikinci Kuvayı Milliye olarak nitelendirmeleri, antiemperyalist tutumları milliyetçi eylemlerinden birkaçıdır. Kurtuluş Savaşı'nın Türkiye'deki bütün uluslar tarafından kazanıldığını düşünen THKO’ya göre hâkim Türk ulusu iktidarı ele geçirmiş ve diğer uluslara yaşam hakkı tanımamıştır. "Yaşasın tam bă̆ımsız Türkiye!” sloganı ile özdeşleşen THKO’da ayrıca “Türk ve Kürt halklarının kardeşliği”" söylemi de sıkça vurgulanmaktadır. Yabancı tehditlere karşı Türkiye halkının birlik olması gerektiğini savunan THKO her ne kadar ulusların kendi kaderlerini tayin hakkına saygı gösterdiklerini söylese de onlara göre bağımsız bir Kürt Devleti de Kürt burjuvazisine hizmet etmekten başka bir işe yaramayacaktır. Çünkü Türk-Kürt işçiler arasındaki dayanışmanın arasında bir engel oluşturacaktır. $\mathrm{Bu}$ nedenle Kürtlerin kendi kaderlerini tayin etmeleri için en uygun yöntem bölgesel özerkliktir. Milletleri ele alış tarzları incelendiğinde THKO’nun etnik köken farklılıklarını kabul ettikleri göze çarpmaktadır. Anadolu coğrafyasında yaşayan tüm etnik grupları Kurtuluş Savaşı ile bağdaştırmak istemektedirler.

THKP-C de MDD'deki milliyetçi söylemlerden rahatsız olarak ayrılan bir gruptur. MDD lideri Belli’nin Kürt halklarını Misak-1 Milli içerisinde değerlendirmesine karşı çıkmışlar ve Kürtlerin kendi kaderlerini tayin haklarını vurgulamışlardır. Ancak THKP-C de bağımsız bir Kürt devletinin tamamen burjuvaya hizmet edeceğini; bu nedenle özerklik ya da federasyon şeklinde bir yönetim biçimi tanınması gerektiği taraftarıdır. Çayan'a göre sosyalistler milliyetçi değildir ancak yurtseverdir.

TKP-ML de MDD'deki milliyetçi söylemlerden dolayı ayrılan bir diğer gruptur. Mihri Belli’yi “azgın bir hâkim ulus milliyetçisi” olarak tanımlayan TKP-ML lideri Kaypakkaya'nın da radikal bir Kürt Milliyetçisi olduğu yorumu yapılabilecektir. Nitekim Türk Solundaki akımlarda da vurgulanan ulusların kendi kaderlerini tayin hakkı düşüncesinin sadece sözde olduğunu düşünmektedirler. Çünkü TKP-ML'ye göre konu bağımsız bir Kürt devleti kurulması olduğunda, devlet kurma hakkı sadece Türklere tanınmakta ve demagoji yapılmaktadır. TKPML milletleri Stalinci bir bakış açısıyla ele alarak halk-millet ayrımı yapmıştır. Buna göre halklar eskiden beri vardır ve yok olmayacaklardır ancak milletler kapitalizmle birlikte doğdukları gibi kapitalizmle birlikte batacaklardır. Millet, dil, toprak, ekonomik yaşam ve ruhi şekillenmede birlik demektir. Onlara göre Kürt milleti kapitalizmle birlikte ortaya çıkmıştır ancak Kürt halkı ezelden beridir vardır. Aşikâr bir şekilde Kürt Milliyetçisi olan Kaypakkaya ve TKP-ML'nin de enternasyonalizme yakın oldukları söylenemeyecektir. 
Cumhuriyet'in ilanı sonrası devam eden 27 yıllık tek parti iktidarı, muhalif hareketlere ve özellikle de sol hareketlere sıcak bakmamıştır. Demokrat Parti'nin iktidara gelmesinden sonra da kapitalizm ile daha da fazla entegre olan Türkiye'de sol düşünceler için bir değişim yaşanmamış; faaliyetler gizli bir şekilde devam ettirilmiştir. 1961 Anayasası'nın sağladığı görece özgürlükçü ortamda sol hareketler kendilerini ifade edebilme şansı yakalamışlar ve çeşitli formlarda siyaset sahnesine dâhil olmuşlardır.

Siyasal ortam özgürlükçü olsa da 1960 darbesi ile iktidarı ele geçiren ordunun subaylarının hemen hemen hepsi Cumhuriyet'in askeri okullarında; Atatürk'ün karizmasının 1şığında eğitim görmüşlerdir (Ahmad, 2012, s. 148). Bunun da farkında olan sol hareketler ordu ile ters düşmek istememişlerdir. Hem orduya karşı zararsız görünmek hem de arkalarına kitlesel destek sağlayabilmek için milliyetçilik söylemleri ön planda tutulmuştur. Bilhassa TíP gibi, mücadelesini anayasal zeminde vermeye çalışan bir hareket için hem ordu ile iyi geçinmek hem de halk desteği almak hayati derecede önemlidir. Ancak yine de Yön, TİP ve MDD' de bariz bir Türk milliyetçiliğgi vurgusu mevcuttur. Bu vurgunun da sadece meşruiyet sağlamak ya da pragmatizmle değerlendirmek son derece yanlış olacaktır. Bu vurgu ayrıca Türk Solu'nun, egemen ideoloji olan Kemalizm'in etkisinden çıkamadıklarının bir göstergesi de olabilir. Yine Kurtuluş Savaşı'nın antiemperyalist niteliği ve akabinde de emperyalist devletlerin talepleri olan bağımsız Kürt devleti ya da Büyük Ermenistan gibi talepler de bu hareketleri savunmacı bir milliyetçilik anlayışına yöneltmiş olabilir.

Benzeri bir refleksin etkileri THKO ve THKP-C hareketlerinde de görülmektedir. $\mathrm{Bu}$ hareketlerin Milliyetçiliğe bir antiemperyalist tepki olarak yaklaştıkları söylenebilecektir. Eylemlerini ilerleyen zamanlarda gerilla hareketine dönüştüren bu hareketlerin meşruiyet sağlamak ya da pragmatist davranmak gibi bir gayelerinin olmadığı yorumu yapılabilecektir, nitekim böyle bir dertleri de yoktur. Belki THKO liderlerinin bir Türk milliyetçiliği çizgisinden koparak zamanla Kürt halkı üzerine vurgularını artırması, gerilla mücadelesinde Kürtlerden kitlesel bir destek sağlayabilme gayesi açısından pragmatist bir davranış olarak ele alınabilir. TKP-ML hareketi ise yürüttüğü Kürt Milliyetçiliği politikasına, sol hareketlerden kitlesel destek bekleyen pragmatist bir yaklaşımla ele alınabilir.

\section{Kaynakça}

Ağırnasl1, N. (1964). Türkiye İş̧̧i Partisi radyo konuşmalarl yurt sorunlarl ve çözüm yolu içinde (Derleyen: TiP Ankara İli Araştırma ve Yayın Bürosu). Ankara: Kardeş Matbaası.

Ağırnaslı, N. (1967). Milliyetçilere çağrı. Türk Solu, 3, s. 5

Ahmad, F. (2012). Modern Türkiye’nin oluşumu (11. Basım). (Çeviren: Y. Alogan). İstanbul: Kaynak Yayınları. 
Akın, Y. (2008). Türkiye Sol Hareketinin Önemli Polemikleri. Modern Türkiye'de Siyasi Düşünce Cilt: 8 Sol (2. Bask1) (Editör: M. Gültekingil) içinde ss. 86-103. İstanbul: İletişim Yayınları.

Aksakal, H. (2009). “Güler Yüzlü” bir Sosyalist, ilkeli bir siyasetçi: Mehmet Ali Aybar'ın Türk siyasal yaşamındaki yeri ve önemi. SDÜ Fen Edebiyat Fakültesi Sosyal Bilimler Dergisi, 20, s. 79-102

Altan, Ç.(1962). Yaşasın Liberalizm. Yön, 1, s. 9

Ataöv, T. (1962). Türk Sosyalizmine doğru. Yön, 12, s. 14

Atılgan, G. (2017). '68'in kapıları. Türkiye’nin 1960’lı Yılları içinde (Hazırlayan: M. K. Kaynar). ss. 315340. İstanbul: İletişim Yayınları.

Avcıoğlu, D. (1962a). Sosyalizm anlayışımız. Yön, 36, s. 3.

Avcıŏlu, D. (1962b). Yapıcı Milliyetçilik. Yön, 4, s. 3

Avcioğlu, D. (1962c). Kaynağa dönüş. Yön, 47, s. 2

Avcıoğlu, D. (1965). Az gelişmiş ülkelerde antiemperyalist mücadele halkçı, devletçi, devrimci ve milliyetçi kalkınma yolu. Yön, 111, s. 8-9

Avcıŏglu, D. (1966a). Sınıf mücadelesi, sosyalizm ve milliyetçilik. Yön, 182, s. 3.

Avc1oğlu, D. (1966b). TïP'e dair. Yön, 168, s. 3

Aybar, M. A. (1947). Her şeyden evvel ve her şeyin üstünde istiklal. Zincirli Hürriyet, 1(1), s. 4

Aybar, M. A. (1964). Türkiye İşçi Partisi radyo konuşmaları yurt sorunları ve çözüm yolu içinde (Derleyen: TiP Ankara İli Araştırma ve Yayın Bürosu). Ankara: Kardeş Matbaası.

Aybar, M. A. (2015). Türkiye Sosyalizmi. Türkiye Sosyalist Solu Kitabı 1 (3. Baskı) içinde (Hazırlayan: E. A. Türkmen). ss. 127-165. Ankara: Dipnot Yayınları.

Ayçiçek, E. (2020). Türkiye Sosyalist Hareketi: Özgün ve Milli. Milliyetçilik içinde (Editör: T. Erdem), ss. 1033-1049, İstanbul: Otorite.

Aydemir, Ş. S. (1962a). Don Kişot'un yel değirmeni İle savaşı. Yön, 9, s.7

Aydemir, Ş. S. (1962b). Sosyalizm ve Kapitalizm. Yön, 37, s. 20

Aydemir, Ş. S. (1963). Türk Sosyalizminin ilkeleri. Yön, 56, s. 8

Aydın, S. (1998). "Millî Demokratik Devrim”den "Ulusal Sol”a Türk solunda özgücü eğilim. Toplum ve Bilim, 78, ss. 59-91.

Aydın, S. (2008a). Sosyalizm ve Milliyetçilik: Galiyefizm'den Kemalizm'e Türkiye'de üçüncü yol arayışları. Modern Türkiye'de Siyasi Düşünce Cilt: 4 - Milliyetçilik (3. Baskı) (Editör: T. Bora) içinde. ss. 438482. İstanbul: İletişim Yayınları

Aydın, S. (2008b). Türkiye Solunda özgücülük ve milliyetçilik. Modern Türkiye'de Siyasi Düşünce Cilt: 8 Sol (2. Bask1) (Editör: M. Gültekingil) içinde ss. 543-577. İstanbul: İletişim Yayınları.

Başkaya, F. (2008). Türkiye'de sol hareketin ideolojik geri planı üzerine bazı göndermeler. Modern Türkiye'de Siyasi Düşünce Cilt: 8-Sol (2. Bask1) (Editör: M. Gültekingil) içinde ss. 73-77. İstanbul: İletişim Yayınları.

Bayrak, M. (T.Y.). Sinemilliler: Bir Kürt - Alevi Aşireti. Erişim tarihi: 26.11.2020 https://kulseyyid.com/sinemilliler-bir-kurt-alevi-asireti/

Bektaş, M. (2015). Kemalizm ve Sosyalizm. Ankara: İmge Kitabevi. 
Belge, M. (2008). Marksizm'in “Millileşmesi” mi, "Yerlileşmesi” mi?. Modern Türkiye'de Siyasi Düşünce Cilt: 8 - Sol (2. Baskı) (Editör: M. Gültekingil) içinde ss. 105-113. İstanbul: İletişim Yayınları.

Belli, M. (1969). Millet gerçeği. Aydınlık Sosyalist Dergi, 7, s. 23-39.

Belli, M. (2015). Milli Demokratik Devrim. Türkiye Sosyalist Solu Kitabı 1 (3. Baskı) içinde (Hazırlayan: E.

A. Türkmen). s. 199-264. Ankara: Dipnot Yayınları.

Behram, N. (2001). Darağacında ü̧̈ fidan. İstanbul: Everest Yayınları.

Bora, T. (2018). Cereyanlar Türkiye'de siyasi ideolojiler (6. Bask1). İstanbul: İletişim Yayınları.

Bostancı, M.N. (1999). Bir kolektif bilinç olarak milliyetçilik. İstanbul: Doğan Kitapçılık.

Cihangir, E. (2020). Milliyetçilik ve Sosyalizm. Milliyetçilik içinde (Editör: T. Erdem), 200-217, İstanbul:

Otorite.

Çayan, M. (2015). Aydınlık Sosyalist Dergi'ye açık mektup. Türkiye Sosyalist Solu Kitabı 1 (3. Baskı) içinde (Hazırlayan: E. A. Türkmen). s. 335-359. Ankara: Dipnot Yayınları

Dünya Bankas1 (2020). Population total, Turkey. Erişim Tarihi: 25.11.2020, https://data.worldbank.org/indicator/SP.POP.TOTL?locations=TR

Ekinci, T. Z. (1964). Türkiye İşçi Partisi radyo konuşmalarl yurt sorunları ve çözüm yolu içinde (Derleyen: TİP Ankara İli Araştırma ve Yayın Bürosu). Ankara: Kardeş Matbaası.

Erdem, T. (2020). Milliyetçilik. Milliyetçilik içinde (Editör: T. Erdem), ss. 28-52, İstanbul: Otorite.

Erten, B. (2008). Doğu Perinçek. Modern Türkiye'de siyasi düşünce Cilt: 4 - Milliyretçilik (3. Baskı) (Editör: T. Bora) içinde. ss. 462-482. İstanbul: İletişimim Yayınları

Gellner, E. (2018). Uluslar ve ulusçuluk (3. Baskı) (Çevirenler: B. Ersanlı ve G. G. Özdoğan). İstanbul: Hill Yayın.

Heywood, A. (2012). Siyaset (6. Baskı) (Çevirenler: B. B. Özipek, B. Şahin, M. Yıldız, Z. Kopuzlu, B. Seçilmişoğlu, A. Yayla). Ankara: Adres Yayınları.

İnan, H. (2015). Türkiye devriminin yolu. Türkiye Sosyalist Solu kitabı 1 (3. Bask1) içinde (Hazırlayan: E. A. Türkmen). ss. 425-490. Ankara: Dipnot Yayınları.

Karaman, S. (1967). Milliyetçilik nedir? Türk Solu, 3, s. 2

Karan, M. (1962). Kemalizm ve Türk Sosyalizmi. Yön, 39, s. 6

Karpat, K. H. (2015). Türk siyasi tarihi (6. Bask1). İstanbul: Timaş Yayınları

Kaya, Y. ve Yücer, R. (2018). Kadro ve Yön hareketlerinin ideolojik analizi. Insan ve Toplum Bilimleri Araştırmaları Dergisi, 7(2), ss. 561-582

Kaypakkaya, İ. (2015). Türkiye'de milli mesele. Türkiye Sosyalist Solu Kitabı 1 (3. Baskı) içinde (Hazırlayan: E. A. Türkmen). ss. 491-556. Ankara: Dipnot Yayınları.

Kaypakkaya, İ. (2016a). Türkiye'de milli mesele. İbrahim Kaypakkaya Bütün Eserleri (7. Baskı) içinde. İstanbul: Nisan Yayınc1lı.

Kaypakkaya, İ. (2016b). TïKP program taslağı eleştirisi. İbrahim Kaypakkaya Bütün Eserleri (7. Baskı) içinde. İstanbul: Nisan Yayıncılık. 
Kaypakkaya, İ. (2016c). Şafak revizyonizminin, Kemalist Hareket, Kemalist İktidar Dönemi, İkinci Dünya Savaşı Yılları, savaş sonrası ve 27 Mayıs Hakkındaki Tezler. İbrahim Kaypakkaya Bütün Eserleri (7. Baskı) içinde. İstanbul: Nisan Yayıncılık.

Kaypakkaya, İ. (2016d). Şafak revizyonizmi ile ayrıldığımız başlıca noktalar. İbrahim Kaypakkaya Bütün Eserleri (7. Baskı) içinde. İstanbul: Nisan Yayıncılık.

Kışlalı, A.T. (2017). Siyasal sistemler siyasal çatışma ve uzlaşma. İstanbul: Kırmızı Kedi Yayınevi.

Koç, E. (2010). Behice "Bir devrimci... Bir kadın ... Bir anne...”. İstanbul: Destek Yayınevi

Odabaş1, Levent (2017). Fikir Kulüplerinden Devrimci Gençliğe. Türkiye'nin 1960’lı Yılları içinde (Hazırlayan: Mete Kaan Kaynar). ss. 341-358. İstanbul: İletişim Yayınları.

Oktay, A. (1998). Türk Solu ve kültür. Toplum ve Bilim, 78, ss. 38-58.

Özbay, T. (2019). Ŭgur Mumcu Kemalizm ve Sosyalizm (3. Bask1). Ankara: Telgrafhane Yayınları.

PDA (1970). Proleter enternasyonalizmi ve burjuva milliyetçiliği. Proleter Devrimci Aydınlık, 8-22. ss. 261272.

Perinçek, D. (1970a). “İki Taktik” üzerine. Proleter Devrimci Aydınlık. ss. 225-240

Perinçek, D. (1970b). Marksizm-Leninizm-Mao Zedung Düşüncesi Bütün İnsanlığın Malıdır. Proleter Devrimci Ayrdinlı, 10(24). ss. 479-496.

Sayın, M. (2008). Milliyetçilik ve Demokrasi Arasında Sol Düşünce. Modern Türkiye'de Siyasi Düşünce Cilt: 8 - Sol (2. Bask1) (Editör: M. Gültekingil) içinde ss. 578-584. İstanbul: İletişim Yayınları.

Sülker, K. (1964). Türkiye İş̧̧i Partisi Radyo Konuşmaları Yurt Sorunları ve Çözüm Yolu içinde (Derleyen: TíP Ankara İli Araştırma ve Yayın Bürosu). Ankara: Kardeş Matbaası.

TíP (1964). Türkiye İş̧̧i Partisi Programı. İstanbul: Ersa Matbaacılık.

TiP (1965). Türkiye İşçi Partisi Seçim Bildirisi. İstanbul: Yenilik Basımevi.

Tï (1969a). Türkiye İşçi Partisi Tüzüğü (8. Baskı). Ankara: Balkanoğlu Matbaacılık.

TiP (1969b). Türkiye İş̧i Partisi El Kitabı. Ankara: Çınar Matbaası.

Tunçay, M. (2001). TKP Lideri Mustafa Suphi İktisat Vekili!. Başka Bir Tarih ve Başka Bir Türkiye içinde (Derleyen: S. Öngider). ss. 193-203. İstanbul: Aykırı Yayınları.

Turan, E. (2017). Siyaset. Konya: Palet Yayınları.

Türkeş, A. (2019). Milli Doktrin 9 Işılk. İstanbul: Bilge Karınca.

Ünüvar, K. (2008). Doğu Perinçek. Modern Türkiye'de Siyasi Düşünce Cilt: 8 - Sol (2. Baskı) (Editör: M. Gültekingil) içinde ss. 710-723. İstanbul: İletişim Yayınları.

Yanık, A. ve Bora, T. (2017). Altmışlı Yıllarda Türkiye'nin Siyasi Düşünce Hayatı. Türkiye'nin 1960’lı Yılları içinde (Hazırlayan: M. K. Kaynar). s. 275-300 İstanbul: İletişim Yayınları.

Yardımoğlu, O. (2015). Bir Türk Aydınının İdeolojik Seyri: Doğu Perinçek Örneği. Yayımlanmamış Doktora Tezi. İzmir: Dokuz Eylül Üniversitesi Sosyal Bilimler Enstitüsü.

Yurtsever, H. (2008). Yükseliş ve Düşüş Türkiye Solu 1960-1980. İstanbul: Yordam Kitap.

Zürcher, E.J. (2020). Modernleşen Türkiye'nin Tarihi (4. Baskı), (Çeviren: Y. Saner). İstanbul: İletişim. 